Singer, H. V., S. M. Slattery, L. Armstrong, and S. Witherly. 2020. Assessing breeding duck population trends relative to anthropogenic disturbances across the boreal plains of Canada, 1960-2007. Avian Conservation and Ecology 15(1):1. https://doi.org/10.5751/ACE-01493-150101

Copyright (C) 2020 by the author(s). Published here under license by the Resilience Alliance.

Research Paper, part of a Special Feature on Conservation of Boreal Birds

\title{
Assessing breeding duck population trends relative to anthropogenic disturbances across the boreal plains of Canada, 1960-2007
}

\author{
Howard V. Singer ${ }^{1}$, Stuart M. Slattery ${ }^{1}$, Llwellyn Armstrong ${ }^{1}$ and Susan Witherly ${ }^{2}$ \\ ${ }^{1}$ Institute for Wetland and Waterfowl Research, Ducks Unlimited Canada, Stonewall, Manitoba, ${ }^{2}$ Formerly: Institute for Wetland \\ and Waterfowl Research, Ducks Unlimited Canada, Stonewall, Manitoba
}

\begin{abstract}
Impacts of anthropogenic disturbance on duck populations in the boreal forest is largely unknown but hypothesized to negatively influence abundance through top-down and bottom-up processes. We examined relationships between population trajectory of duck pairs and anthropogenic disturbances in the Boreal Plains ecozone of western Canada by first controlling for habitat and then assessing whether population trends were related to density of seismic lines, pipelines, roads, and well sites, and distance to agriculture to help focus conservation efforts on the most limiting changes. We also evaluated whether these relationships differed in agriculture encroached vs. unencroached landscapes; distance to agriculture was assessed in unencroached landscapes. Pair counts (1960-2007) obtained from the Waterfowl Breeding Population and Habitat Survey were pooled into nesting guilds (cavity, ground, and overwater). All anthropogenic disturbance features were time invariant. Annual moisture data was used to control for effects of annual variation in breeding season weather. Variation in relative magnitude and direction of effect size indices among anthropogenic disturbances depended on both landscape and nesting guild. Overall, majority of negative relationships occurred with seismic lines and pipelines, while distance to agriculture was positive. Population trends for ground nesters, which suggest overall declines, tended be most negative in regions with high seismic line and well pad density in encroached landscapes and with high seismic line and pipeline density in unencroached landscapes. Cavity nester population trends were generally positive throughout the study area but were lowest in unencroached landscapes farthest from agriculture. Overwater nester trends were generally lowest in encroached landscapes with high densities of seismic lines, roads, and well pads and in unencroached landscapes with high densities of seismic lines, pipelines, and roads. Although our work suggests that anthropogenic disturbances, particularly seismic and pipelines, may merit further consideration as foci for conservation, additional research is needed to quantify demographic implications.
\end{abstract}

\section{Évaluation des tendances de population de canards nicheurs relativement aux perturbations d'origine anthropique dans les Plaines boréales du Canada, 1960-2007}

RÉSUMÉ. Les effets de perturbations d'origine anthropique sur les populations de canards nichant en forêt boréale sont grandement inconnus, mais on les soupçonne d'influer négativement sur l'abondance des canards par l'action de processus ascendant et descendant. Nous avons examiné les relations existant entre les tendances de population de canards nicheurs et les perturbations d'origine anthropique dans l'écozone des Plaines boréales dans l'ouest du Canada, en contrôlant pour l'habitat dans un premier temps, puis en évaluant si les tendances de populations étaient liées à la densité de tracés sismiques, de pipelines, de routes et de puits, et à la distance aux activités agricoles, afin de contribuer à diriger les efforts de conservation sur les changements les plus contraignants. Nous avons aussi évalué si ces relations différaient en fonction d'où elles se trouvaient, soit en paysage agricole ou non. La distance aux activités agricoles a été évaluée dans le cas des paysages sans empiètement agricole. Les dénombrements de couples (1960-2007) provenant du Relevé des populations nicheuses et des habitats de sauvagine ont été regroupés en guildes pour le type de nidification (cavité, au sol ou sur l'eau). Aucune des sources de perturbations d'origine anthropique n'a varié dans le temps. Des données annuelles de précipitation ont été utilisées pour contrôler les effets de la variation annuelle de la météo lors de la saison de reproduction. La variation de l'intensité relative et de la direction des indices d'intensité des effets des différentes perturbations d'origine anthropique dépendaient des types de paysages et de guildes de nidification. En général, la majorité des relations négatives se sont manifestées avec les tracés sismiques et les pipelines, alors que la distance aux activités agricoles présentait une relation positive. La tendance des populations de canards qui nichent au sol, laquelle montre une baisse dans l'ensemble, était le plus négative dans les régions où la densité de tracés sismiques et de puits était élevée pour les paysages présentant de l'empiètement et où la densité de tracés sismiques et de pipelines était élevée pour les paysages sans empiètement anthropique. La tendance des populations de canards cavicoles était généralement positive dans l'aire d'étude, mais était le plus faible dans les paysages sans empiètement les plus éloignés d'activités agricoles. La tendance des canards nichant sur l'eau était généralement au plus bas dans les paysages avec empiètement et des densités élevées de tracés sismiques, de routes et de puits, et dans les paysages sans empiètement et des densités élevées de tracés sismiques, de pipelines et de routes. Bien que nos travaux indiquent que les perturbations d'origine anthropique, en particulier les tracés sismiques et les pipelines, mériteraient d'être scrutées davantage comme avenues de conservation, d'autres recherches sont nécessaires pour quantifier les répercussions sur le plan démographique.

Key Words: anthropogenic disturbance; Boreal Plains; distance to agriculture; ducks; habitat; linear disturbances; pipelines; population trends; roads; seismic lines; well sites; Western Boreal Forest 


\section{INTRODUCTION}

The western boreal forest represents important breeding habitat for many avian taxa including waterfowl (Environment Canada 2013, Prairie Habitat Joint Venture 2014) and contains more lakes and wetlands than any other ecosystem in the world (Foote and Krogman 2006). This region supports an estimated breeding population of $12-15$ million ducks of 23 species, second only to the Prairie Pothole Region in continental importance for breeding waterfowl (Slattery et al. 2011). Since the 1970s, cumulative population counts for nine duck species that have $\geq 25 \%$ of their surveyed breeding area population in the western boreal forest have declined by $\sim 20 \%$, with four of the numerically most important duck species falling below North American Waterfowl Management Plan population goals (Fast et al. 2011, Prairie Habitat Joint Venture 2014).

Reasons for these declines are unknown. However, the Boreal Plains ecozone (Ecological Stratification Working Group 1995) within the western boreal forest is experiencing unprecedented rates of anthropogenic change (Niemi et al. 1998, Schindler 1998, Hobson et al. 2002, Schneider 2002) and expansion in the energy sector footprint is likely to continue for decades (Loss 2016). Timber harvest, petroleum exploration and extraction, agricultural expansion, mining, and hydroelectric development are all intensifying within the western boreal forest (Slattery et al. 2011). Although information relating waterfowl population change to anthropogenic disturbances in the western boreal forest is limited (Pierre 2001), several studies on other avian taxa have documented negative demographic consequences of industrial forest activities (Väisänen et al. 1986, Paton 1994, Hobson and Bayne 2000). Negative relationships with anthropogenic disturbances on waterfowl have been documented in Sweden and Finland (Pöysä et al. 2017), while positive relationships (Lemelin et al. 2007) and no relationships (Börger and Nudds 2014) have been documented in eastern Canadian boreal forest.

Many of these industrial activities require a suite of infrastructure that expands their footprint (Benítez-López et al. 2010, Rooney et al. 2012). Anthropogenic disturbances related to infrastructure include linear corridors for road construction, seismic exploration, oil pipeline routes, and well pad sites. These changes increase fragmentation of forested habitats (Schmiegelow and Mönkkönen 2002) and may create potential travel corridors for predators (James 1999), which could result in increased predation (Hethcoat and Chalfoun 2015). Additionally, where roads are constructed across lotic wetland systems, hydrologic functions also may be altered (Park et al. 2008), potentially reducing food availability for breeding waterfowl. Thus, there may be top-down (predation-related) and bottom-up (hydrological) processes related to resource extraction development that could be limiting waterfowl populations (Slattery et al. 2011). However, hydrologic impairment caused by roads may be analogous to beaver dams (Martell et al. 2006, Holopainen et al. 2014), creating more open water habitat than would be present otherwise, and so uncertainty remains about the net effects of roads, and other industrial infrastructure, on waterfowl population trends.

Agricultural encroachment into the western boreal forest along its southern boundary (Hobson et al. 2002, Schmiegelow and Mönkkönen 2002) fundamentally alters the landscape matrix, changing it from largely forested to one dominated by pastures and cropland interspersed with remnant forest patches, likely ranging widely in size (Lindenmayer and Fischer 2006). These patches are potentially further fragmented by linear corridors and well pads. Conversion of natural uplands to cropland also can be accompanied by wetland drainage (Blann et al. 2009). This shift in matrix may alter habitat quality for waterfowl near agriculture. For example, agriculture may act as a source habitat permitting immigration of novel predators into nearby forested landscapes (Bayne and Hobson 1997). The result can be greater predator diversity along forest-agricultural edges, as has been observed for songbirds in the southern Boreal Plains (Bayne and Hobson 1997). Furthermore, greater avian predator density, e.g., ravens, and nest predation rates have been observed in forested habitat as agriculture presence increased (Andren 1992). These changes are hypothesized to alter duck nesting success and hen survival (Slattery et al. 2011), and as such merit investigation for conservation action, currently occurring in forested landscapes mainly under the auspices of the Prairie Habitat Joint Venture partnership (Prairie Habitat Joint Venture 2014).

Success of conservation programs requires that associated activities are directed at stressors to wildlife populations that are most relevant for a given landscape context. The Boreal Plains clearly has a variety of industrial activities on which conservation could focus. However, variation in relative importance of these stressors in forested landscapes encroached by agriculture (hereafter agriculture encroached) and those that are not (hereafter unencroached) is unknown, creating uncertainty around which habitat changes conservation should focus on in these different landscapes. The goal of this paper is to help guide conservation action in the Boreal Plains toward mitigating for the most important landscape changes potentially limiting waterfowl populations, and thereby help avoid or mitigate negative effects of anthropogenic disturbances if they exist. Specifically, we assessed covariation between duck breeding season population trajectories and recent amount of anthropogenic disturbances in both agriculture encroached and unencroached boreal landscapes. We predicted that local duck abundance would decline with increasing densities of seismic lines, pipelines, roads, and well sites and decreasing distance to agriculture because of potential top-down and bottom-up effects on settling. Given the high degree of forest fragmentation in agriculture encroached landscapes, we also expected that anthropogenic disturbances associated with infrastructure would have stronger relationships in unencroached landscapes where they make up a larger component of disturbances. Finally, we anticipated that patterns would vary across nesting guilds, given variation in life history traits.

\section{METHODS}

\section{Study area}

Our study focused on the Boreal Plains ecozone in Canada's western boreal forest (Ecological Stratification Working Group 1995). The $740,000 \mathrm{~km}^{2}$ area stretches northwest from southern Manitoba to northeastern British Columbia (Fig. 1). Because of underlain thick glacial sedimentation (Klassen 1989) and equal annual precipitation and evapotranspiration (Woo and Winter 1993), the ecozone has an abundance of wetland habitats. The wetlands fall into five distinct habitats: bogs, fens, marsh, open 
water, and swamps, which occupy between $25-50 \%$ of the ecozone (Vitt 1994). Mean annual temperature and precipitation range from $-2^{\circ} \mathrm{C}-+2^{\circ} \mathrm{C}$ and $300 \mathrm{~mm}-625 \mathrm{~mm}$ in northern Alberta and southern Manitoba, respectively (Ecological Stratification Working Group 1995). Dominant tree species include balsam fir (Abies balsamea), balsam poplar (Populus balsamifera), black spruce (Picea mariana), jack pine (Pinus banksiana), tamarack (Larix laricina), trembling aspen (Populus tremuloides), white spruce (Picea glauca), and white birch (Betula papyrifera).

Fig. 1. Study area within the Boreal Plains ecozone. Boundary corresponds to the U.S. Fish and Wildlife Service Breeding Population and Habitat Survey (WBPHS) area within this region. Study area is only that portion of the Boreal Plains that is surveyed by the WBPHS.

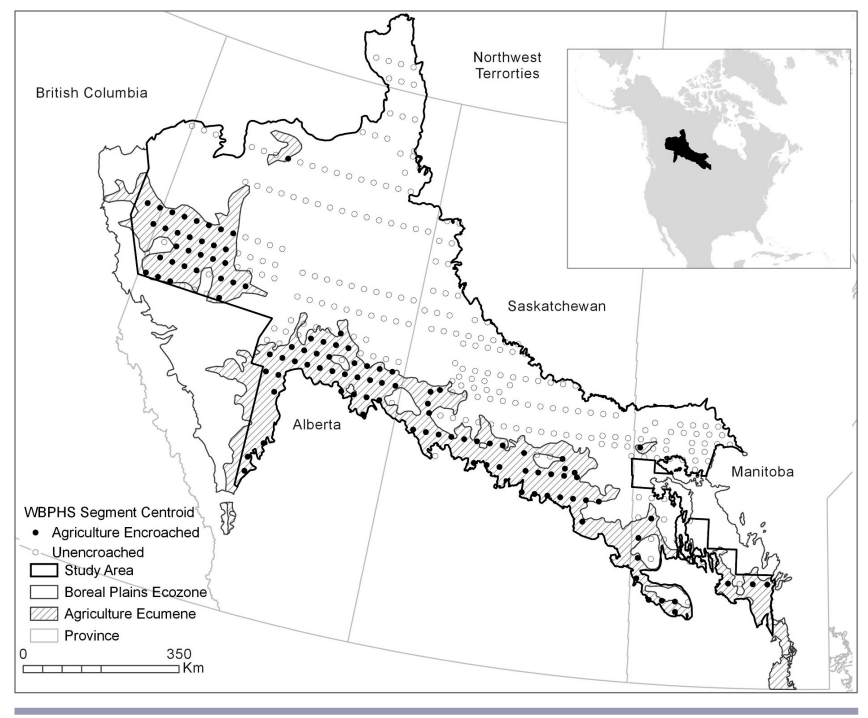

\section{Data}

\section{Duck data}

We used Waterfowl Breeding Population and Habitat Survey (hereafter BPOP) data collected on survey segments $(n=346)$ located in survey strata 17, $20-27,30-31,36-37,40$, and 75-77 from 1960 to 2007 (United States Fish and Wildlife Service and Canadian Wildlife Service 1987; Fig. 1). Data on certain survey segments was not collected on all years, however, $\sim 50 \%$ of survey segments had $\geq 40$ years of data and $\sim 15 \%$ of survey segments had $\leq 30$ years of data, with surveys typically beginning in the 1980s-1990s as survey segments were added to the BPOP. BPOP surveys were flown using a pilot/observer and observer on opposite sides of the plane counting all waterfowl spotted within $200 \mathrm{~m}$ of each side of the aircraft along fixed transects mostly several hundred kilometers in length. Surveys are flown at a fixed altitude of $30-50 \mathrm{~m}$ and a ground speed of $\sim 200 \mathrm{~km} / \mathrm{h}$ (Smith 1995). Within transects, counts are binned into $\sim 28.8 \mathrm{~km}$ long segments. We only included BPOP segments in our analyses if $>$ $50 \%$ of segment area was within the Boreal Plains ecozone boundary (Ecological Stratification Working Group 1995). Furthermore, we omitted segments where water composed $>50 \%$ of total segment area because these segments typically represented large lake systems not normally used by breeding waterfowl. Because of low segment-level counts of most species and presumed variation in nesting habitat influencing sensitivity to landscape changes, we categorized each species into one of three nesting guilds (ground, overwater, and cavity nesters; Table 1). We then used visibility-corrected pair counts (Smith 1995) at the segment-level pooled within guilds as our response variable. Visibility correction factors are obtained through annual surveys of a subsample of segments where ground crews are assumed to count every bird. The total counts from ground surveys are used to estimate correction factors applied to the aerial survey counts, to obtain a true census.

Table 1. Species composition within guild and percent segments with zero observations.

\begin{tabular}{|c|c|c|}
\hline $\begin{array}{l}\text { Nesting Guild } \\
\text { Species }\end{array}$ & $\begin{array}{l}\% \text { segments } \\
\text { with zero } \\
\text { observations }\end{array}$ & $\begin{array}{c}\% \text { species } \\
\text { composition } \\
\text { within } \\
\text { guild } \\
\end{array}$ \\
\hline \multicolumn{3}{|l|}{ Ground } \\
\hline Mallard (Anas platyrhynchos) & $20-25$ & 41 \\
\hline Green-winged Teal (Anas crecca) & $60-70$ & 13 \\
\hline Generic Scaup (Aythya spp.) & $50-60$ & 13 \\
\hline Blue-winged Teal (Anas discors) & $60-70$ & 11 \\
\hline American Wigeon (Anas americana) & $60-70$ & 10 \\
\hline Northern Shoveler (Anas clypeata) & $60-70$ & 5 \\
\hline Gadwall (Anas strepera) & $70-75$ & 3 \\
\hline Northern Pintail (Anas acuta) & $75-80$ & 3 \\
\hline Generic Scoter (Melanitta spp.) & $90-5$ & 1 \\
\hline Long-tailed Duck (Clangula hyemalis) & $>99$ & $<1$ \\
\hline American Black Duck (Anas rubripes) & $>99$ & $<1$ \\
\hline \multicolumn{3}{|l|}{ Overwater } \\
\hline Ring-necked Duck (Aythya collaris) & $75-80$ & 47 \\
\hline Canvasback (Aythya valisineria) & $80-90$ & 29 \\
\hline Redhead (Aythya americana) & $80-90$ & 18 \\
\hline Ruddy Duck (Oxyura jamaicensis) & $90-95$ & 7 \\
\hline \multicolumn{3}{|l|}{ Cavity } \\
\hline Bufflehead (Bucephala albeola) & $50-60$ & 63 \\
\hline Generic Goldeneye (Bucephala spp.) & $75-80$ & 20 \\
\hline $\begin{array}{l}\text { Generic Merganser (Lophodytes } \\
\text { cucullatus and Mergus spp.) }\end{array}$ & $75-80$ & 17 \\
\hline
\end{tabular}

\section{Habitat and anthropogenic disturbance data}

Upland and wetland habitat variables for each segment were derived from Ducks Unlimited Canada's Hybrid Wetland Layer (N. Jones unpublished report), previously used for modeling duck distributions (Barker et al. 2014). The Hybrid Wetland Layer was derived from the Earth Observation for Sustainable Development of Forests project (EOSD; Natural Resources Canada 2007). The Hybrid Wetland Layer utilized a $25 \mathrm{~m}$ pixel resolution and amalgamated some of the 36 EOSD classes resulting in 21 unique habitat classes. We then omitted 7 classes, which consisted of approximately $3 \%$ of the total land cover derived from the 21 unique habitat classes. For our analysis, we utilized the remaining 14 unique classes by combining similar habitat types to create 7 classes, which represent our habitat covariates. Habitat covariates were open water, wetland, coniferous forests, deciduous forests, mixedwood forests, crop, and shrub. We extracted percentage area of all open water (PERC_OPWA), wetland (PERC_WETL), and upland habitats (PERC_CONI, PERC_MIXE, PERC_DECI, PERC_CROP, PERC_SHRU) within $200 \mathrm{~m}$ and $1000 \mathrm{~m}$ buffers around each segment's center line to include as habitat covariates. 
Anthropogenic disturbance spatial data came from several sources with varying date-of-capture because there is not one seamless source. Pipeline and well site data were obtained from IHS Markit ${ }^{\circledR}$ (2016, https://ihsmarkit.com). Seismic line and road data for Alberta were derived from the Alberta Biodiversity Monitoring Institute's human footprint map circa 2007 (ABMI 2009). Linear features data from other provinces came from Global Forest Watch (GFW 2009). Densities for each anthropogenic linear disturbance (i.e., pipelines, roads, and seismic lines; PIPE_DEN, ROAD_DEN, SEIS_DEN) were then calculated as $\mathrm{km} / \mathrm{km}^{2}$ present within each $(200 \mathrm{~m}$ and $1000 \mathrm{~m})$ buffered segment. For well sites (WELL), we used the number of unique well sites present within each buffered segment. For areas without available disturbance data we assumed no disturbance was present.

Agricultural disturbance spatial data was derived from the agriculture ecumene boundary layer (Statistics Canada 2016). The agriculture ecumene boundary defines areas primarily dominated by agriculture from those primarily dominated by forested lands. We used this boundary to define two covariates for agricultural disturbance; $D$ (distance to agriculture) and Landscape_Ag, which is a binary indicator of whether a segment is within an agriculture encroached landscape, e.g., $>50 \%$ of total buffer area within the agricultural ecumene boundary (Landscape_Ag $=1)$, or not (Landscape_Ag $=0$ ). Distance to agriculture was calculated as the distance from segment centroid to the nearest border of the agriculture ecumene boundary for unencroached segments only.

Last, we wanted to control for annual variation in segment level moisture surplus/drought on local population trends, and so included annual estimates of Palmer's drought index (National Agroclimate Information Service 2018) for May. This month was selected because the index reflects both current and antecedent moisture conditions and we wanted our seasonal weather metric to correspond with BPOP survey timing in this region (May). For each year (1960-2007), we used May Palmer drought index values from 143 weather stations within the boreal plains to create interpolated surfaces using inverse distance weighting (to preserve input values). Interpolated Palmer drought index values (PDI) within buffered segments were averaged to obtain year-specific values for each survey segment and year. All spatial data were processed using Environmental Systems Research Institute, ArcMAP 10.1 (ESRI, Redlands, California, USA).

\section{Statistical analyses}

\section{Selection of covariate measurement scale}

To avoid high collinearity among habitat composition, anthropogenic disturbance, and weather variables between concentric buffers $(200 \mathrm{~m}$ and $1000 \mathrm{~m})$, we selected a single best scale for each variable by examining changes in variance ratios with increasing buffer size. Our goal was to select buffer distances that captured the greatest heterogeneity in predictor covariates. We wanted to retain as much intersegment variance as possible (Cunningham and Johnson 2016). Because $1000 \mathrm{~m}$ buffers consisted of five times the area of $200 \mathrm{~m}$ buffers, we expected a $5^{2}$ increase in intersegment variance because of area change alone. If heterogeneity increased with buffer width, we expected variance ratios $>25$. Likewise, if greater buffer widths tended to decrease heterogeneity, expected variance ratios would be $<25$. Thus, we used $1000 \mathrm{~m}$ buffers when variance ratios were $>25$ and used 200 $m$ buffers otherwise.

\section{Basic random coefficient model}

We modelled visually corrected total pairs using linear mixedeffects models with random coefficients; count regression methods were not appropriate because the data were not nonnegative integers (Longford 1993, Littell et al. 1996). We square root-transformed the response variable to stabilize variances. We examined relationships between time varying segment-level duck pair densities and time invariant anthropogenic disturbance variables, while controlling for effects of spatially variable habitat composition and interannual variation in spring weather variables. Random coefficient models are appropriate when data arise from a series of nested experimental units, e.g., segments within the Boreal Plains. The basic premise behind random coefficients modeling is that each segment has its own underlying temporal trajectory with respect to population size. These trajectories can be viewed as deviations (random coefficients) from a region-wide trend. Habitat covariates are postulated to affect the average segment-specific pair numbers, i.e., the intercept of segment-specific temporal trends in pairs. We used the Palmer drought index to account for spatially variable annual habitat availability effects on yearly pair densities. We predicted that anthropogenic disturbance variables coupled with landscape (agriculture encroached vs unencroached) affected the temporal trajectory of duck abundance, i.e., the slope of segment-specific temporal trends. Thus, anthropogenic disturbance covariates enter the model only through their interactions with year and landscape effects. The following is an example of the model structure, with the simplifying assumptions of percent coniferous as the only habitat composition covariate and seismic line density as the only anthropogenic density covariate:

$$
\begin{aligned}
& \text { (Visibility Corrected-Pairs } \left.\mathrm{ij}_{\mathrm{ij}}\right)=\left(\beta_{0}+\mathrm{b}_{0 \mathrm{i}}\right)+\left(\beta_{1}+\mathrm{b}_{1 \mathrm{i}}\right) * \mathrm{Ys}_{\mathrm{j}}+ \\
& \left(\beta_{2}+\mathrm{b}_{2 \mathrm{i}}\right) * \mathrm{Ys}_{\mathrm{j}}^{2}+\beta_{3} * \mathrm{PDI}_{\mathrm{ij}}+\beta_{4} * \mathrm{PERC}_{-} \mathrm{CONI}_{\mathrm{i}}+\beta_{5} * \mathrm{Ys}_{\mathrm{j}}{ }^{*}
\end{aligned}
$$

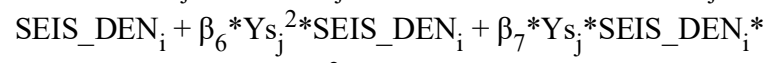

$$
\begin{aligned}
& \text { Landscape_Ag }{ }_{\mathrm{i}}+\beta_{8} * \mathrm{Ys}_{\mathrm{j}}{ }^{2}{ }^{*} \text { SEIS_DEN }{ }_{\mathrm{i}}{ }^{*} \text { Landscape }_{-} \mathrm{Ag}_{\mathrm{i}}+\beta_{9} * \\
& \mathrm{Ys}_{\mathrm{j}} * \mathrm{D}_{\mathrm{i}} * \text { Landscape_Ag } \mathrm{i}_{\mathrm{i}}+\beta_{10} * \mathrm{Ys}_{\mathrm{j}}{ }^{2} * \mathrm{D}_{\mathrm{i}} * \text { Landscape_Ag } \mathrm{Ag}_{\mathrm{i}}+\varepsilon_{\mathrm{ij}}
\end{aligned}
$$

where $\mathrm{Ys}_{\mathrm{j}}=$ Year $_{\mathrm{j}}-1960$

$\mathrm{i}=1, \ldots$, I segments

$\mathrm{j}=1, \ldots, \mathrm{T}_{\mathrm{j}}$ years

$\beta_{\mathrm{o}}$ is the fixed intercept

$\beta_{1}, \ldots, \beta_{10}$ are fixed effects

$\mathrm{b}_{0 \mathrm{i}}$ are random intercepts $\sim \mathrm{N}\left(0, \sigma^{2}{ }_{\mathrm{b} 0}\right)$

$\mathrm{b}_{1 \mathrm{i}}, \mathrm{b}_{2 \mathrm{i}}$ are random coefficients $\sim \mathrm{N}\left(0, \sigma^{2}{ }_{1}\right), \mathrm{N}\left(0, \sigma^{2}{ }_{2}\right)$

$\varepsilon_{\mathrm{ij}} \sim \mathrm{MVN}(0, \mathbf{R})$ where $\mathbf{R}$ is comprised of I block diagonal elements, $\Sigma_{\mathrm{i}}$, with

u,vth element $\sigma_{\mathrm{uv}}=\sigma^{2 *} \rho^{\text {abs(u-v); }}$

this is a standard autoregressive structure with declining correlation among the observations on a segment as the number of years between observations increases. Spatial error structure was not explicitly included but would have been accounted for to some degree through the random coefficients.

Linear and quadratic temporal trends were estimated by summing the estimates of: (i) the overall fixed effect estimate $\left(\beta_{1}\right.$ or $\left.\beta_{2}\right)$, (ii) 
random linear/quadratic effect estimate $\left(b_{1 \mathrm{i}}\right.$ or $\left.b_{2 \mathrm{i}}\right)$, (iii) products of each estimated anthropogenic disturbance covariate's variable effect and its associated value (e.g., $\beta_{5}{ }^{*}$ [SEIS_DEN ${ }_{\mathrm{i}}$ ] or $\beta_{6}{ }^{*}$ [SEIS_DEN $\left.]_{\mathrm{i}}\right]^{2}$ ), and (iv) adjustments to (iii) for agriculture encroached segments (e.g., $\beta_{7}^{*} \quad$ [SEIS_DEN $\mathrm{i}_{\mathrm{i}}$ or $\beta_{8}^{*}$ $\left.[\text { SEIS_DEN }]_{\mathrm{i}}\right]^{2}$ ). The distributions of anthropogenic and agricultural disturbance covariates were right-skewed. All were therefore square-root transformed to reduce the impact of outlying values on effect estimates.

\section{Two-stage modeling process}

We used a two-stage modeling process to determine which habitat covariates to include in the combined anthropogenic disturbance, weather, agriculture, and landscape models. First, we fit habitat screening models using only quadratic temporal trends and a set of habitat compositions (PERC_OPWA, PERC_WETL, PERC_CONI, PERC_MIXE, PERC_DECI, PERC_CROP, PERC_SHRU) as covariates. A backwards stepwise elimination procedure was used by removing the least informative variable from the model at each step, starting from a full model that included main effects only and continued until all habitat variables were removed. The best-approximating model was identified via Akaike Information Criterion (hereafter AIC, Burnham and Anderson 2002). Habitat variables appearing in the best habitatonly model were then included as intercept adjustments of population trajectory in combined anthropogenic disturbance, weather, agriculture, and landscape models. We used a backwards elimination procedure that terminated when all fixed covariate effects were removed. Model hierarchy was preserved during elimination and AIC was used to determine the best approximating model for each guild (Appendix 1). We report results for models $\leq 4 \mathrm{AIC}$ units from the best model. All models were fit using SAS software (SAS v. 9.4, Cary, NC, USA).

\section{Model fit}

We calculated both marginal (including only the contributions of fixed effects of year, landcover, Palmer's drought index, and anthropogenic disturbance variables) and conditional (including the contributions of both fixed effects and random intercept-and year-adjustments) versions of $\mathrm{R}^{2}$ GLMM. We calculated Spearman's correlation between the observed and predicted data and an extension of Nakagawa and Schielzeth's $\mathrm{R}_{\text {GLMM }}^{2}$ for random coefficients models (Johnson 2014) as measures of goodness-offit.

\section{Calculation of effect sizes}

To better understand relative importance of habitat variables, we estimated expected percent change in pair density with a $5 \%$ increase in habitat composition covariates retained in bestapproximating anthropogenic disturbance models for each guild. Holding all other model covariates constant at mean levels, we estimated duck pair densities at mean habitat composition (e.g., percent coniferous) $+/-2.5$ percentage points and computed the corresponding percent change in pair density. For anthropogenic disturbance variables, relationships between duck pair density (pairs per $\sim 1150$ ha segment) and these variables were plotted for all variables retained in best approximating models for each guild at the 25th (low), 50th (medium), and 75th (high) percentiles. Percentiles were calculated based on data combined across landscapes. We then calculated an index of effect size for each anthropogenic disturbance and agricultural disturbance variable by determining the percent change in waterfowl density from 1960 to 2007 for the 25 th and 75 th percentiles for each landscape. We subtracted the 25 th from 75 th for nonagricultural anthropogenic disturbances. Because segments with smaller distances to agriculture represent higher levels of agriculture disturbance, we subtracted the 75 th from 25 th for distance to agriculture. A negative value indicated a negative relationship between distance to agriculture or anthropogenic disturbance and waterfowl populations. We compared these effects across guilds.

Finally, to visualize spatial variation in cumulative (additive) effects of anthropogenic disturbance variables across the Boreal Plains, we mapped predicted percent change in population size from 1960 to 2007. We used model predictions, parameter estimates, and coefficients from the top model for each guild at a spatial resolution equivalent in size to the survey segment area of $\sim 1150$ ha to calculate percent change. Because our interest was effects of anthropogenic disturbance variables, we included all fixed effects for these variables and controlled for other effects by setting habitat and weather variables to mean values.

\section{RESULTS}

\section{Buffer widths}

Ratios of segment variability for $1000 \mathrm{~m}$ and $200 \mathrm{~m}$ buffers were greater than expected for all variables except ROAD_DEN and PDI. Therefore, we used the $200 \mathrm{~m}$ buffer for ROAD_DEN and PDI and $1000 \mathrm{~m}$ buffer for all others.

\section{Habitat screening models}

We retained PERC_CONI for all guilds. PERC_CROP, PERC_WETL, PERC_MIXE, and PERC_SHRU were retained for ground and cavity nesters. PERC_OPWA was retained for cavity and overwater nesters (Appendix 2). Pair density was negatively correlated with PERC_CONI for all nesting guilds. PERC_OPWA was positively correlated with cavity and overwater nesters pair density. PERC_MIXE, PERC_SHRU, PERC_CROP, and PERC_WETL were negatively correlated with cavity and ground nesters (Appendix 2).

\section{Anthropogenic disturbance models}

Models including random coefficients of the quadratic term for year yielded singular covariance matrices. We therefore removed this random effect to achieve model identification (Matuschek et al. 2017).

\section{Ground nesters}

Top models (<4 AIC from best model) accounted for $91 \%$ of model weight, and the following anthropogenic disturbance variables appeared in top models consisting only of informative parameters, i.e., excluding models with extra parameters but comparable fit to simpler models (as measured by maximized loglikelihood; Arnold 2010): Landscape x SEIS_DEN x $\mathrm{Ys}^{2}$, Landscape x PIPE_DEN x Ys ${ }^{2}$, Landscape x WELL x Ys ${ }^{2}$, and ROAD_DEN x year ${ }^{2}$ (Table 2). In addition, highest-order anthropogenic disturbance model coefficients were well estimated (beta/SE ratios exceeded 1.5; Table 3). The estimated standard deviations of the random intercepts and linear effects of year for the top model were 3.52 and 0.054 , respectively. Estimated temporal autocorrelation ( $\rho)$ was 0.29 . 
Table 2. Model selection for ground nesting ducks based on anthropogenic disturbance models. For models within four $\Delta$-AIC units of the best-fit model, only informative models are shown (Arnold 2010). Also shown are intercept and full models.

\begin{tabular}{|c|c|c|c|c|c|}
\hline Fixed Effects Model Form & $\mathrm{k}$ & $\begin{array}{c}-2^{x} \log \\
\text { Likelihood }\end{array}$ & AIC & $\triangle \mathrm{AIC}$ & $\begin{array}{l}\text { Model } \\
\text { weight }\end{array}$ \\
\hline $\begin{array}{l}\text { PERC_SHRU + PERC_MIXE + PERC_CROP + PERC_CONI + PERC_WETL + PDI + Ys } \mathrm{s}^{2 \dagger}+ \\
\text { Landscape } \mathrm{x} \text { SEIS_DEN } x \mathrm{Ys}^{2}+\text { Landscape } \mathrm{x} \text { WELL } \mathrm{x} \mathrm{Ys}^{2}+\text { Landscape } \mathrm{x} \text { PIPE_DEN x } \mathrm{Ys}^{2}+ \\
\text { ROAD_DEN x Ys }{ }^{2}\end{array}$ & 27 & 69562.16 & 69616.16 & 0.00 & 0.54 \\
\hline $\begin{array}{l}\text { PERC_SHRU + PERC_MIXE + PERC_CROP + PERC_CONI + PERC_WETL + Ys }{ }^{2 \dagger}+\text { Landscape } x \\
\text { SEIS_DEN x Ys }{ }^{2}+\text { Landscape } x \text { WELL } x \mathrm{Ys}^{2}+\text { Landscape } x \text { PIPE_DEN x Ys }{ }^{2}+\text { ROAD_DEN x Ys }{ }^{2}\end{array}$ & 26 & 69564.92 & 69616.92 & 0.76 & 0.37 \\
\hline $\begin{array}{l}\text { Full Model: PERC_SHRU + PERC_MIXE + PERC_CROP + PERC_CONI + PERC_WETL + PDI + } \\
\mathrm{Ys}^{2} \dagger+\text { Landscape } x \text { SEIS_DEN x Ys }{ }^{2}+\text { Landscape } \mathrm{x} \text { WELL } x \mathrm{Ys}^{2}+\text { Landscape } x \text { PIPE_DEN x } \mathrm{Ys}^{2}+ \\
\text { Landscape } \mathrm{x} \text { ROAD_DEN x Ys } \mathrm{S}^{2}+\mathrm{D} \times \mathrm{Ys}^{2}\end{array}$ & 31 & 69559.21 & 69621.21 & 5.05 & $\S$ \\
\hline Intercept only & $4^{*}$ & 70254.85 & 70262.85 & 646.69 & $<0.01$ \\
\hline
\end{tabular}

${ }^{\dagger}$ Models containing either/both $\mathrm{Ys}^{2}$ or Covariate* $\mathrm{Ys}^{2}$ imply that Ys or Covariate*Ys is also included in the model in order to preserve model hierarchy.

Intercept only model includes parameter estimates for fixed intercept, variance of the random intercept, autoregressive parameter $\rho$, error variance.

${ }^{8}$ Not used to calculate model weight as this model contains uninformative parameters.

On average, populations of ground nesting ducks declined by $55 \%$ and $60 \%$ from 1960 to 2007 in agriculture encroached (Landscape_Ag = 1) and unencroached landscapes (Landscape_Ag $=0$ ), respectively. Indices of effect size for anthropogenic disturbance variables ranged from $-16 \%$ to $18 \%$ (Table 4 ). Direction and magnitude of these indices were similar across landscapes for seismic line density and to a lesser extent road density, while pipelines and wells varied in direction but not magnitude. Overall, direction and magnitude of anthropogenic disturbance variables differed between landscapes, and negative indices were observed in seismic lines and wells in agriculture encroached segments and seismic lines and pipelines in the unencroached landscape.

\section{Cavity nesters}

Top models accounted for $98 \%$ of model weight, and models with informative parameters had the following anthropogenic disturbance variables: PIPE_DEN x Ys ${ }^{2}$, ROAD_DEN x Ys ${ }^{2}$, and $\mathrm{D} \times \mathrm{Ys}$ (Table 5). The top three models differed in the form or lack of PIPE_DEN effect. No landscape effect was observed. In addition, highest-order anthropogenic disturbance model coefficients were well estimated (Table 3 ). The standard deviations of the random intercepts and linear effects of year for the top model were 0.94 and 0.020 , respectively. Estimated temporal autocorrelation was 0.14 .

On average, populations of cavity nesting duck pairs increased by $290 \%$ from 1960 to 2007 . Indices of effect size for anthropogenic disturbance variables ranged from -39 to $147 \%$, and only pipelines had a negative relationship with population trends while roads and distance to agriculture were positive (Table 4).

\section{Overwater nesters}

Top models accounted for $90 \%$ of model weight, with the following anthropogenic disturbance variables included in top models with informative parameters: Landscape $x$ SEIS_DEN x $\mathrm{Ys}^{2}$, Landscape x PIPE_DEN x Ys ${ }^{2}$, Landscape $\mathrm{x}$ WELL x $\mathrm{Ys}^{2}$, and D x Ys (Table 6). In addition, highest-order anthropogenic disturbance model coefficients were well estimated (Table 3 ). The standard deviations of the random intercepts and linear effects of year for the top model were 1.08 and 0.016 , respectively. Estimated temporal autocorrelation was 0.14.
On average, populations of overwater nesting ducks increased by about $36 \%$ or declined by about $29 \%$ from 1960 to 2007 in the agriculture encroached and unencroached landscapes, respectively. Indices of effect size for anthropogenic disturbance variables ranged from -71 to $114 \%$ (Table 4 ). Direction and magnitude of anthropogenic disturbance variables differed between landscapes for pipelines and wells, with negative effects of pipelines in unencroached landscapes and negative effects of wells in agriculture encroached landscapes. Seismic lines and roads had negative indices in both landscapes. All effect indices except roads were stronger in agriculture encroached landscapes than unencroached segments. Distance to agriculture was positive.

\section{Model fit}

Marginal $\mathrm{R}_{\text {GLMM }}^{2}$ estimates for cavity, ground, and overwater nesters were $0.12,0.21$, and 0.13 , respectively. Conditional $\mathrm{R}^{2}$ GLMM estimates for cavity, ground, and overwater nesters were $0.47,0.64$, and 0.47 , respectively. Differences between the marginal and conditional $\mathrm{R}_{\text {GLMM }}^{2}$ values indicate the random coefficients for the intercept and year effects contributed substantially to model fit. Spearman correlation estimates of the actual year*segment-specific values vs model predictions, i.e., incorporating both fixed and random effects, for cavity, ground, and overwater nesters were $0.66,0.76$, and 0.66 , respectively.

\section{Distribution of anthropogenic disturbance and cumulative effects on populations}

Anthropogenic disturbances can be found throughout the Boreal Plains but are most intense within the agriculture ecumene along the southern fringe of our study area (Fig. 2). Predicted percent change in population size from 1960 - 2007 for ground nesters was generally lower in unencroached landscapes with greater densities of anthropogenic disturbances than areas with less anthropogenic disturbance (Fig. 2 vs. Fig. 3). Overall, ground nesters declined across the Boreal Plains with greatest declines across Alberta, where significant anthropogenic disturbances have occurred. Percent change in cavity nesters was highest within the agriculture ecumene boundary, particularly in Manitoba and Saskatchewan where less anthropogenic disturbance occurred (Fig. 3). Percent change was lower, albeit mainly positive, with increasing distance from that boundary, such that slightly negative 
Table 3. Beta $(\beta)$ and SE for anthropogenic disturbance and agriculture variables from best approximating model for all nesting guilds.

\begin{tabular}{|c|c|c|c|}
\hline & Cavity Nesters & Ground Nesters & Overwater Nesters \\
\hline Covariate & $\beta(\mathrm{SE})$ & $\beta(\mathrm{SE})$ & $\beta(\mathrm{SE})$ \\
\hline Ys & $0.0415(0.0087)$ & $0.0261(0.0245)$ & $0.0050(0.0097)$ \\
\hline $\mathrm{Ys}^{2}$ & $-0.0004(0.0001)$ & $-0.0014(0.0004)$ & $0.0001(0.0001)$ \\
\hline SEIS_DEN*Ys & . & $-0.0015(0.0043)$ & $-0.0055(0.0015)$ \\
\hline SEIS_DEN*Ys ${ }^{2}$ & . & $-0.00004(0.00007)$ & $0.0001(0.00003)$ \\
\hline SEIS_DEN*Ys*Landscape_Ag & . & $0.0134(0.0068)$ & $0.0034(0.0023)$ \\
\hline SEIS_DEN*Ys ${ }^{2} *$ Landscape_Ag & . & $-0.0003(0.0001)$ & $-0.00009(0.00004)$ \\
\hline ROAD_DEN*Ys & $-0.0064(0.0030)$ & $-0.0217(0.0092)$ & $-0.0051(0.0056)$ \\
\hline ROAD_DEN*Ys ${ }^{2}$ & $0.0002(0.00005)$ & $0.0005(0.0002)$ & $0.00008(0.0001)$ \\
\hline ROAD_DEN*Ys*Landscape_Ag & . & . & $0.0118(0.0053)$ \\
\hline ROAD_DEN ${ }^{*} \mathrm{Ys}^{2} *$ Landscape_Ag & . & . & $-0.0002(0.0001)$ \\
\hline $\mathrm{D} * \mathrm{Ys}$ & $-0.0012(0.0004)$ & . & $-0.0013(0.0004)$ \\
\hline $\mathrm{D} * \mathrm{Ys}^{2}$ & . & . & . \\
\hline PIPE_DEN*Ys & $0.0017(0.0016)$ & $0.0125(0.0100)$ & $0.0074(0.0035)$ \\
\hline PIPE_DEN*Ys ${ }^{2}$ & $-0.00005(0.00003)$ & $-0.0004(0.0002)$ & $-0.0002(0.00006)$ \\
\hline PIPE_DEN*Ys*Landscape_Ag & . & $-0.0385(0.0174)$ & $-0.0232(0.0061)$ \\
\hline PIPE_DEN* ${ }^{*}{ }^{2}{ }^{*}$ Landscape_Ag & . & $0.0010(0.0003)$ & $0.0006(0.0001)$ \\
\hline WELL*Ys & . & $-0.0015(0.0089)$ & $0.0022(0.0030)$ \\
\hline WELL*Ys ${ }^{2}$ & . & $0.00007(0.0002)$ & $-0.00002(0.00005)$ \\
\hline WELL*Ys*Landscape_Ag & . & $0.0351(0.0171)$ & $0.0098(0.0059)$ \\
\hline WELL*Ys ${ }^{2} *$ Landscape_Ag & . & $-0.0008(0.0003)$ & $-0.0003(0.0001)$ \\
\hline
\end{tabular}

Table 4. Indices of effects size for anthropogenic disturbance variables in agriculture encroached (AG) and unencroahced (Forest) landscapes from the best approximating model for each nesting guild (Tables 2, 5, and 6). Signs indicate direction of relationship (positive trend increasing, negative trend decreasing). See Methods, Calculation of effect sizes, for calculation method, Table 3 for associated parameter estimates, and Appendix 3 for graphical representation of relationships. Identical effect sizes within guilds across landscapes for anthropogenic disturbance variables imply no landscape effect. Distance to $\mathrm{Ag}$ was not measured in AG landscapes.

\begin{tabular}{|c|c|c|c|c|c|c|}
\hline \multirow[b]{2}{*}{$\begin{array}{l}\text { Anthropogenic } \\
\text { Disturbance }\end{array}$} & \multicolumn{2}{|c|}{ Ground } & \multicolumn{2}{|c|}{ Cavity } & \multicolumn{2}{|c|}{ Overwater } \\
\hline & $\mathrm{AG}$ & Forest & $\mathrm{AG}$ & Forest & $\mathrm{AG}$ & Forest \\
\hline Seismic & -16 & -14 & 0 & 0 & -60 & -22 \\
\hline Pipeline & 18 & -13 & -39 & -39 & 114 & -51 \\
\hline Road & 3 & 3 & 147 & 147 & -21 & -31 \\
\hline Wells & -12 & 8 & 0 & 0 & -71 & 44 \\
\hline Distance to Ag & NA & 0 & NA & 98 & NA & 59 \\
\hline
\end{tabular}

changes were predicted for the most distant and relatively pristine areas in the Northwest Territories. Overall, cavity nesters increased, most strongly within the agricultural ecumene in all provinces. Overwater nesters generally showed similar trends as cavity nesters in unencroached landscapes with lower percent changes in relatively pristine areas (Fig. 3). However, unlike cavity nesters, the most negative changes were observed within the agriculture ecumene particularly in Alberta where high densities of anthropogenic disturbance existed. Overall, overwater nesters remained relatively stable, despite areas of strong positive and negative change.
Fig. 2. Anthropogenic disturbance variables' densities across the study area.

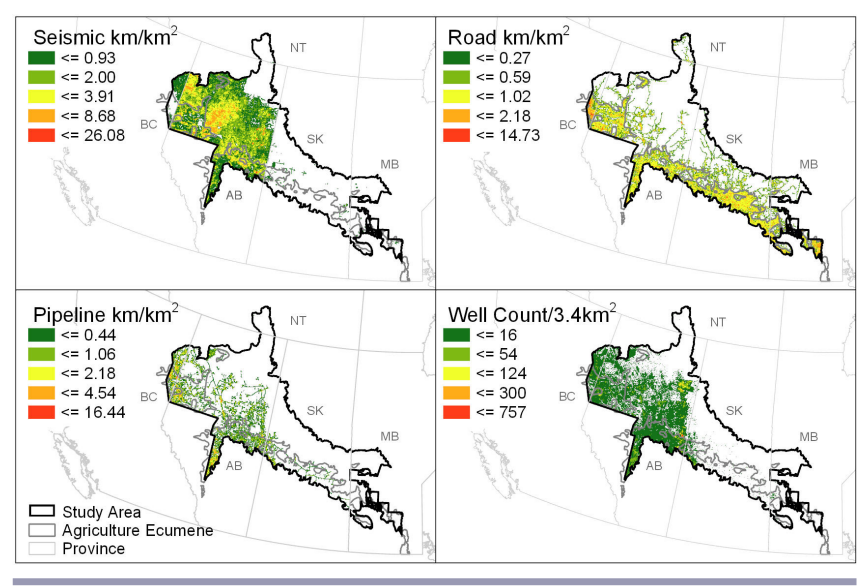

\section{DISCUSSION}

This research represents the first assessment of relationships between anthropogenic disturbances and duck population trends across the Boreal Plains. Our goals were to identify anthropogenic disturbances in this region that may merit further attention as targets for duck conservation and determine whether their relative importance varied in the agricultural encroached vs unencroached landscapes. We found that patterns of covariation between duck population trends and seismic line, pipeline, road, and well pad density, and distance to agriculture were complex. Indices of effect sizes, hence potential relative importance of these features as conservation targets, did vary across landscapes for ground and overwater nesters, but not for all anthropogenic 
Table 5. Model selection for cavity nesting ducks based on anthropogenic disturbance models. For models within four $\Delta$-AIC units of the best-fit model, only informative models are shown (Arnold 2010). Also shown are intercept and full models.

\begin{tabular}{|c|c|c|c|c|c|}
\hline Fixed Effects Model Form & $\mathrm{k}$ & $\begin{array}{c}-2^{x} \log \\
\text { Likelihood } \\
\end{array}$ & AIC & $\triangle \mathrm{AIC}$ & $\begin{array}{l}\text { Model } \\
\text { weight }\end{array}$ \\
\hline $\begin{array}{l}\text { PERC_SHRU + PERC_MIXE + PERC_CROP + PERC_CONI + PERC_WETL + PERC_OPWA } \\
+ \text { PDI }+\mathrm{Ys}^{2 \dagger}+\text { PIPE_DEN } x \mathrm{Ys}^{2}+\text { ROAD_DEN } x \mathrm{Ys}^{2}+\mathrm{D} \times \mathrm{Ys}\end{array}$ & 19 & 46709.89 & 46747.89 & 0.00 & 0.62 \\
\hline $\begin{array}{l}\text { PERC_SHRU + PERC_MIXE + PERC_CROP + PERC_CONI + PERC_WETL + PERC_OPWA } \\
+\mathrm{PDI}+\mathrm{Ys}^{2 \dagger}+\text { PIPE_DEN } \times \text { Ys }+ \text { ROAD_DEN } \times \mathrm{Ys}^{2}+\mathrm{D} \times \mathrm{Ys}\end{array}$ & 18 & 46713.70 & 46749.70 & 1.82 & 0.25 \\
\hline $\begin{array}{l}\text { PERC_SHRU + PERC_MIXE + PERC_CROP + PERC_CONI + PERC_WETL + PERC_OPWA } \\
+\mathrm{PDI}+\mathrm{Ys}^{2 \dagger}+\text { ROAD_DEN } x \mathrm{Ys}^{2}+\mathrm{D} \times \mathrm{Ys}\end{array}$ & 17 & 46717.40 & 46751.40 & 3.51 & 0.11 \\
\hline $\begin{array}{l}\text { Full Model: PERC_SHRU + PERC_MIXE + PERC_CROP + PERC_CONI + PERC_WETL + } \\
\text { PERC_OPWA + PDI + Ys s } \mathrm{s}^{2 \dagger}+\text { Landscape x SEIS_DEN x Ys }{ }^{2}+\text { Landscape x WELL x Ys }{ }^{2}+ \\
\text { Landscape x PIPE_DEN x Ys } \mathrm{Ys}^{2}+\text { Landscape x ROAD_DEN x } \mathrm{Ys}^{2}+\mathrm{D} \times \mathrm{Ys}^{2}\end{array}$ & 32 & 46695.15 & 46759.15 & 11.26 & $\S$ \\
\hline Intercept only & 4 & 47851.42 & 47859.42 & 1111.53 & $<0.01$ \\
\hline
\end{tabular}

Fig. 3. Percent change in predicted pair density from 1960 to 2007 for ground (top), cavity (middle), and overwater (bottom) nesting pairs. Estimates were capped at $300 \%$. Average indicates mean population trend for each guild.

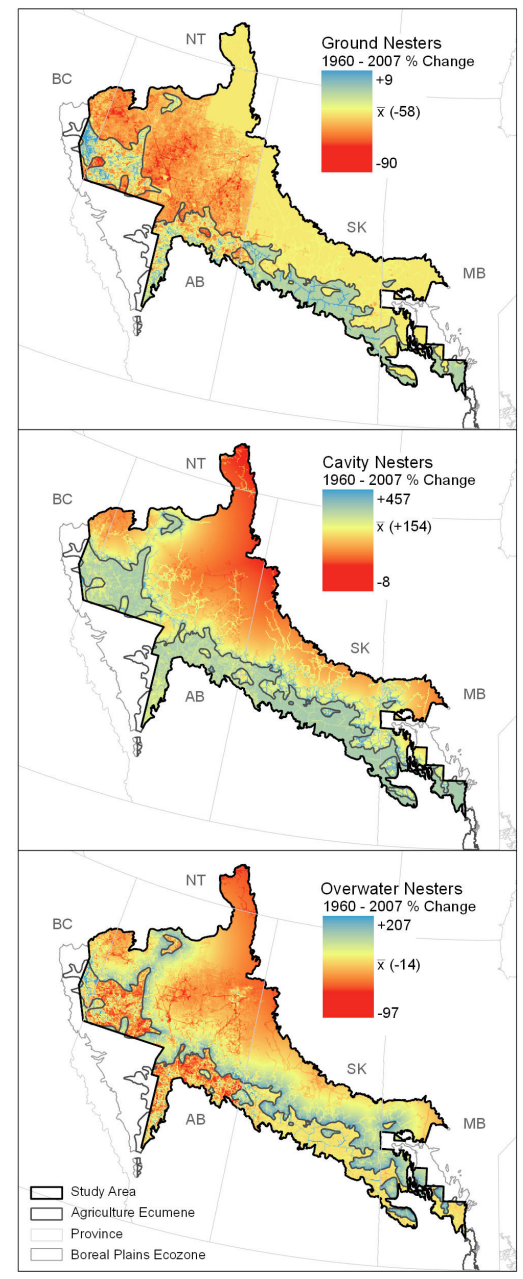

disturbance types. The degree of variation across landscapes was dependent on nesting guild and disturbance type, but anthropogenic disturbance variables had slightly numerically stronger relationships in agriculture encroached vs unencroached landscapes in six of seven cases where the effect size differed (Table 4).

Of all anthropogenic disturbances, seismic lines and pipelines accounted for most negative relationships, and so these features merit further investigation as potential foci for conservation efforts. Seismic lines and pipelines are fundamentally similar linear features, both referred to as "cut lines" in common vernacular because of similar appearance when viewed from the ground and air (H. Singer, personal observation). These cut lines typically have no above ground infrastructure associated with them, but pipelines are typically wider (Government of Canada 2003). Furthermore, whereas seismic lines are allowed to regenerate, pipeline right of ways are not, which could increase their use by mammalian predators. Our results of negative seismic line relationships in both landscapes for ground and overwater nesters, corroborate other research on wildlife and seismic lines. Although relationships with seismic lines have not been examined for waterfowl until now, negative relationships have been observed with other species (Ovenbirds, Seiurus aurocapilla, Bayne et al. 2005, Machtans 2006; woodland caribou, Rangifer tarandus caribou, Dyer et al. 2001, but see Dyer et al. 2002). These patterns have been attributed to increased predation risk, with seismic lines serving as travel corridors, potentially resulting in greater predator aggregation or increased hunting success (James 1999, James and Stuart-Smith 2000, Smith 2004, Tigner 2012). It has been hypothesized that linear features such as seismic lines and pipelines provide easier access to prime nesting habitat for duck predators such as red fox (Vulpes vulpes, Slattery et al. 2011). Negative relationships with pipelines were only observed with cavity nesting ducks and there was no landscape effect. Curiously, about $70 \%$ of pipelines in the agriculture encroached landscape were in croplands, where most surficial evidence was likely eliminated by tilling, and so with limited habitat features for predators to orient. Thus, negative effects here were likely driven 
Table 6. Model selection for overwater nesting ducks based on anthropogenic disturbance models. For models within four $\Delta$-AIC units of the best-fit model, only informative models are shown (Arnold 2010). Also shown are intercept and full models.

\begin{tabular}{|c|c|c|c|c|c|}
\hline Fixed Effects Model Form & $\mathrm{k}$ & $\begin{array}{c}-2^{\mathrm{x}} \log \\
\text { Likelihood } \\
\end{array}$ & AIC & $\Delta \mathrm{AIC}$ & $\begin{array}{l}\text { Model } \\
\text { weight }\end{array}$ \\
\hline $\begin{array}{l}\text { PERC_CONI + PERC_OPWA + Ys² + Landscape x SEIS_DEN x Ys² + Landscape x } \\
\text { PERC_PIPE x Ys }{ }^{2}+\text { Landscape x WELL x Ys }{ }^{2}+\text { Landscape x ROAD_DEN x Ys }{ }^{2}+D \times \mathrm{Ss}^{2}\end{array}$ & 26 & 48902.36 & 48954.36 & 0.00 & 0.73 \\
\hline $\begin{array}{l}\text { PERC_CONI + PERC_OPWA + Ys }{ }^{2}+\text { Landscape x SEIS_DEN x Ys + SEIS_DEN x Ys } \mathrm{s}^{2}+ \\
\text { Landscape x PERC_PIPE x Ys }{ }^{2}+\text { Landscape x WELL x Ys }{ }^{2}+\text { Landscape x ROAD_DEN x } \\
\mathrm{Ys}^{2}+\mathrm{D} \text { x Ys }{ }^{2}\end{array}$ & 25 & 48907.20 & 48957.20 & 2.84 & 0.18 \\
\hline $\begin{array}{l}\text { Full Model: PERC_CONI + PERC_OPWA + PDI + Ys }{ }^{2}+\text { Landscape x SEIS_DEN x Ys }{ }^{2}+ \\
\text { Landscape x PERC_PIPE x Ys }{ }^{2}+\text { Landscape x WELL x Ys }{ }^{2}+\text { Landscape x ROAD_DEN x } \\
\mathrm{Ys}^{2}+\mathrm{D} x \mathrm{Ys}^{2}\end{array}$ & 29 & 48900.33 & 48958.33 & 3.97 & $\S$ \\
\hline Intercept only & $4^{\ddagger}$ & 49166.68 & 49174.68 & 220.32 & $<0.01$ \\
\hline
\end{tabular}

by fragmentation in what remnant forested habitat remained if duck predators used these cut lines for travel.

Roads share some attributes of seismic lines and pipelines, in that they are linear features contributing to edges and fragmentation of forested areas, potentially facilitating movement of predators. Furthermore, they also have the potential to block stream systems when not built properly and thereby function as analogs to beaver dams, which can benefit waterfowl (Martell et al. 2006, Holopainen et al. 2014). Thus, developing a priori hypotheses of relationships between roads and population trajectory of ducks was difficult. Our results, of positive, negative, and neutral effects generally conflict with the bulk of literature of road effects on various taxa including birds, where studies concluding negative effects of roads on wildlife outweighed those showing positive effects (Fahrig and Rytwinski 2009). Notably, reptiles and amphibians showed negative effects, birds showed mainly negative or no effects, and effects on mammals varied with size, where small mammals showed positive or no effects and large mammals showed mainly negative effects (Fahrig and Rytwinski 2009). We found that magnitude of effect size indices for roads was consistent across landscapes within guilds but varied among guilds, being essentially neutral, positive, and slightly negative for ground, cavity, and overwater nesters, respectively (3\% for ground nesters, $147 \%$ for cavity nesters, -21 and $-31 \%$ for overwater nesters in agriculture encroached and unencroached landscapes, respectively). However, none of these studies were on waterfowl and studies of the effects of roads on waterfowl are limited. Furthermore, meta-analyses by Benítez-López et al. (2010) also found most, but not all road relationships with bird abundance were negative or neutral. In contrast, Morelli et al. (2014) summarized 94 studies showing positive relationships between roads and birds. Some of these relationships were attributed to (1) road sides creating habitat diversity, (2) road sides providing increased foraging opportunities, (3) roads creating greater water availability, and (4) roadsides providing increased nesting sites and cover for predator avoidance (for a thorough list see Morelli et al. 2014). As well, Roy (2018) found nest and brood survival of Ring-necked ducks (Aythya collaris) increased closer to roads and nest survival near paved roads was higher than near dirt roads. These relationships could be attributed to negative interactions with roads and duck predators such that ducks benefit from increased mortality of/and avoidance of roads by predators (Forman and Alexander 1998, Trombulak and Frissell 2000). Although few of these studies were focused on waterfowl, similar road effects may have contributed to our results. For example, road construction in the boreal forest often creates borrow pits that provide new foraging, nesting, and brood rearing habitat in close proximity to roads (Kuczynski and Paszkowski 2012, Kroening and Ferrey 2013). Furthermore, roads can modify wetland hydrology (Bocking 2015) by redistributing water, nutrients, and sediment (Trombulak and Frissell 2000) on the landscape, creating upstream ponding (increased habitat) and drought-like conditions downstream (decreased habitat; Partington et al. 2016). These changes potentially alter invertebrate and plant communities, with net effects on habitat availability and quality likely being dependent on local conditions. These changes may differentially affect nesting guilds, in our case with no meaningful evidence for strong negative effects of roads and positive effects in four of six possible comparisons for each landscape and nesting guild described in Table 4.

Negative relationships with well sites were only observed in the agricultural landscape, and the effect size index was particularly large for overwater nesting species relative to ground nesters (-12 and -71 for ground and overwater nesters, respectively). About $70 \%$ of wells were found in cropland, where regular activity associated with maintenance may be more visible to prospecting duck pairs. In addition, noise from pumps jacks may carry farther in open landscapes than in forests. Activity and anthropogenic sound have been shown to negatively influence abundance (Bayne et al. 2008, Francis et al. 2011) or community structure (Francis et al. 2009) in other avian taxa, presumably because of avoidance of such features by some species. However, Mallard (Anas platyrhynchos) and Blue-winged Teal (Anas discors) appeared to prefer nesting within $100 \mathrm{~m}$ of well sites in southeastern Alberta (Ludlow and Davis 2018), which they attributed to taller and denser grasses near well sites earlier in the season than 
surrounding areas. It is unknown whether ducks respond similarly to activity and anthropogenic sound, nor what life history characteristics may make overwater nesting species more sensitive to wells or correlated factors compared to ground or cavity nesters.

Agricultural encroachment into the southern boreal forest is prevalent and increasing (Vanderhill 1982, Fitzsimmons 2002, Hobson et al. 2002, Bayley et al. 2013) but distance to agriculture had unexpected results in our study. Nudds and Cole (1991) hypothesized that loss of native cover due to agricultural expansion would negatively influence boreal breeding waterfowl populations through increased predation rates. Reduced duck recruitment in the prairie pothole region also has been attributed to agricultural development, linked to increased predation rates (Sargeant and Raveling 1992) and habitat loss (Beauchamp et al. 1996). Meanwhile, declines in avian populations and reproductive success have been linked to forest fragmentation (Robinson et al. 1995, Hobson and Bayne 2000). Although the boreal forest is still one of the few large, unexploited areas on the globe (Foley et al. 2003), agricultural encroachment in the southern fringe likely would cause increased predation on waterfowl from mammalian predators (red fox, mink, Mustela vison, Banfield 1974, Eagle and Whitman 1987; and striped skunk, Mephitis mephitis) because habitat heterogeneity would likely support predators typically associated with prairie parkland habitats over those formerly associated with forested habitats (Fleming 2001). Furthermore, potential shifts in avian predator communities from Common Raven (Corvus corax, Doyle and Smith 2001) and expansion of Great Horned Owl (Bubo virginianus, Rohner et al. 2001) into the agriculture-forest transition zone (Andren 1992, Sauer et al. 2017), have likely exacerbated effects from novel mammalian predators. Thus, we were surprised to observe populations trends of cavity and overwater nesting ducks being relatively higher closer to agriculture than in segments farther away and ground nesters not being affected by proximity to agriculture. This counterintuitive response may result from several factors. First, the strongest relationship we observed was for the cavity nesting guild, with an effect size index almost two times greater than overwater nesting guild. Cavity nesting species are potentially limited by suitable nesting cavities (Savard 1988, Newton 1994, Pöysä and Pöysä 2002, but see Gauthier and Smith 1987). If habitat heterogeneity created by conversion of forest to agricultural land and human habitation was beneficial for primary cavity excavators (e.g., Northern flicker, Colaptes auratus, Moore 1995), increased abundance of potential nest sites could result in higher pair settling rates compared to more homogenous habitats. Second, removal of trees for pasture or cropland may decrease evapotranspiration (Granger and Pomeroy 1997) and increase runoff rates, potentially contributing more input of water and nutrients to local wetlands (sensu Van der Kamp et al. 1999, Houlahan and Findley 2004). This might be augmented by fertilizer applied to uplands, which may run off into nearby wetland systems (Crumpton and Goldsborough 1998, Hebert and Wassenaar 2001). Collectively, increased water and nutrient loading associated with agriculture may increase wetland productivity, thus increasing use by ducks (Silver et al. 2012).

Spatial patterns in overall percent population change from 1960 to 2007 represented distribution and abundance of different anthropogenic disturbance variables and relative strength and direction of their relationships with population trends. Combinations of anthropogenic disturbance densities varied spatially, producing spatial variation in cumulative effects. For example, percent change in ground nesters was typically most negative in regions with highest densities of anthropogenic disturbances. These areas tended to be dominated by seismic lines, and secondarily by pipelines, particularly outside areas encroached by agriculture. These strong negative percent changes contributed greatly to an overall decline in ground nesters across our study area. Meanwhile, spatial patterns in percent change in cavity and overwater nesters tended to be driven by distance to agriculture, being generally most positive in the southern Boreal Plains and lowest in the northern Boreal Plains where habitat is relatively pristine and segments are farther from agriculture. However, localized negative relationships with pipelines and seismic lines were evident for both guilds in unencroached landscapes, as was the positive relationship with roads in cavity nesters.

We consider our results conservative. First, anthropogenic disturbance variables we used were a measure of development levels at the time of imagery capture, independent of when that development occurred. Although we predicted that duck abundance would be a function of development level, we did not expect the same population trajectories on segments with substantially different development rates, which we could not estimate with most of our data. Thus, segments with different development rates but similar development levels at the time of imagery capture were treated the same in our analyses. We believe this unquantified source of variation could have reduced our ability to detect relationships between duck population trends and anthropogenic disturbances, however, our use of random coefficients helped to capture some of the unmeasured variation. However, to the best of our knowledge, annual anthropogenic disturbance data across the entire time series for our suite of predictors do not exist. Obtaining such data for future analyses would enhance the ability to detect changes on segments with varying rates of development. Second, we focused on the settling period only, when duck pairs choose where to breed. Relationships between anthropogenic disturbances and breeding success may be different than those observed for breeding pair settling if different ecological processes influence female survival, nest success, and/or duckling survival. Furthermore, immigration of pairs from other regions could mask effects of reduced local breeding success (Coulton et al. 2011), creating population sinks. Thus, a more thorough assessment of anthropogenic disturbances as foci for conservation action requires examination of both pair settling and their breeding success. Last, seismic line construction has changed drastically since the 1950s when bulldozers were used to create $\sim 8 \mathrm{~m}$ wide swaths (conventional lines). Beginning around 1980, seismic line construction width was gradually reduced and now is typically $\sim 2-3 \mathrm{~m}$ wide (low-impact lines), typically cut by hand or small machinery (Alberta Environment and Parks 2010). Little research has attempted to disentangle varying effects of conventional vs low-impact seismic lines (but see, Machtans 2006 and Van Rensen et al. 2015) or time since seismic line construction. Our results show that population trajectory for overwater nesters in high seismic line density segments began to increase slightly while that of ground nesters continued to decline around the time low-impact lines were implemented (Fig. A3.3), and so we suggest 
this change in practice could impact guilds differently but does not appear to have appreciably altered relationships with duck populations. However, our modeling approach did not specifically test for varying seismic line width effects. And finally, our approach of using guilds as the response variable will limit the amount of inference that can be drawn for individual species, particularly those that have very low abundance as shown. However, given the sparsity of certain species' abundance at the segment level, we believe this approach is currently the most robust.

The goal of our study was to help focus conservation practices and future research on the most probable limiting anthropogenic disturbances for ducks in the Boreal Plains and assess whether those potential limiting factors varied between forest landscapes encroached by agriculture and those that were not. The most probable limiting anthropogenic disturbances for ground nesters were seismic lines in both landscapes, followed by pipelines in unencroached landscapes, and wells in agriculture encroached landscapes. Cavity nesters appeared to be limited by pipelines. Overwater nesters appeared to be limited by seismic lines and roads in both landscapes as well as by pipelines in unencroached landscapes and well sites in agriculture encroached landscapes. This complexity of varying effect sizes for different guilds between landscapes support the conclusion of Stralberg et al. (2019) that conservation objectives need to be carefully articulated before designing conservation actions. Given the overall negative population trends of ground nesters throughout the forested portion of Alberta and a negative relationship with seismic line density, our results suggest limiting seismic line construction in areas where they are currently absent or rare might help conserve habitat for ground nesting species. However, we propose that further study of relationships between seismic lines and ducks is required before implementing this recommendation. Our work was intended as exploratory and a more robust design assessing annual linear feature data and duck abundance would be beneficial. Although this work has assisted in identification of potential limiting factors to duck populations, additional research is clearly required to assess temporal covariation between duck populations and development rates, covariation of anthropogenic disturbances and breeding success, and underlying ecological processes producing important patterns. Ultimately, understanding these processes will be key to helping ensure that conservation and management efforts focus not only on the appropriate types of anthropogenic disturbances, but also the proper tactics to reduce or otherwise offset demographic limitation.

Responses to this article can be read online at: http://www.ace-eco.org/issues/responses.php/1493

\section{Acknowledgments:}

This project could not have been completed without assistance from several agencies and individuals. We are very thankful to the USFWS for making the BPOP data publicly available. We would like to thank Dave Howerter for helping guide early writing of this manuscript. Also, Richard Warren of Agriculture and Agri-Food Canada provided invaluable weather data. Ducks Unlimited Canada staff N. Jones (former), L. McBlane, J. Morissette (former), A. Richard, and K. Smith all made valuable contributions at various stages of manuscript preparation and Jim Devries provided helpful comments on an early draft. Steve Cumming provided valuable critiques on two drafts that greatly improved this manuscript. Funding was provided by the National Fish and Wildlife Foundation, Conoco Phillips, Alberta Pacific Forest Industries Ltd., and the North American Wetlands Conservation Act.

\section{LITERATURE CITED}

Alberta Biodiversity Monitoring Institute (AMBI). 2009. ABMI Human Footprint Map (2007 Version 4.3). [online] URL: https:// abmi.ca/home/old-data/gis-data/human-footprint-download.html

Alberta Environment and Parks. 2010. Reducing the footprint of seismic exploration. Alberta Environment and Parks, Edmonton, Alberta, Canada. [online] URL: https://open.alberta.ca/ publications/reducing-the-footprint-of-seismic-exploration

Andren, H. 1992. Corvid density and nest predation in relation to forest fragmentation: a landscape perspective. Ecology 73:794-804. https://doi.org/10.2307/1940158

Arnold, T. W. 2010. Uninformative parameters and model selection using Akaike's information criterion. Journal of Wildlife Management 74:1175-1178. https://doi.org/10.1111/j.1937-2817.2010. tb01236.x

Banfield, A. W. F. 1974. The mammals of Canada. University of Toronto Press, Toronto, Ontario, Canada.

Barker, N. K. S., S. G. Cumming, and M. Darveau. 2014. Models to predict the distribution and abundance of breeding ducks in Canada. Avian Conservation and Ecology 9(2):7. https://doi. org/10.5751/ACE-00699-090207

Bayley, S. E., A. S. Wong, and J. E. Thompson. 2013. Effects of agricultural encroachment and drought on wetlands and shallow lakes in the boreal transition zone of Canada. Wetlands 33:17-28. https://doi.org/10.1007/s13157-012-0349-x

Bayne, E. M., S. Boutin, B. Tracz, and K. Charest. 2005. Functional and numerical responses of ovenbirds (Seiurus aurocapilla) to changing seismic exploration practices in Alberta's boreal forest. Écoscience 12:216-222. https://doi.org/10.2980/ i1 195-6860-12-2-216.1

Bayne, E. M., L. Habib, and S. Boutin. 2008. Impacts of chronic anthropogenic noise from energy-sector activity on abundance of songbirds in the boreal forest. Conservation Biology 22:1186-1193. https://doi.org/10.1111/j.1523-1739.2008.00973.x

Bayne, E. M., and K. A. Hobson. 1997. Comparing the effects of landscape fragmentation by forestry and agriculture on predation of artificial nests. Conservation Biology 11:1418-1429. https://doi. org/10.1046/j.1523-1739.1997.96135.x

Beauchamp, W. D., R. R. Koford, T. D. Nudds, R. G. Clark, and D. H. Johnson. 1996. Long-term declines in nest success of prairie ducks. Journal of Wildlife Management 60:247-257. https://doi. org/10.2307/3802222

Benítez-López, A., R. Alkemade, and P. A. Verweij. 2010. The impacts of roads and other infrastructure on mammal and bird 
populations: a meta-analysis. Biological Conservation 143:1307-1316. https://doi.org/10.1016/j.biocon.2010.02.009

Blann, K. L., J. L. Anderson, G. R. Sands, and B. Vondracek. 2009. Effects of agricultural drainage on aquatic ecosystems: a review. Critical Reviews in Environmental Science and Technology 39:909-1001. https://doi.org/10.1080/10643380801977966

Bocking, E. C. 2015. Analyzing the impacts of road construction on the development of a poor fen in Northeastern Alberta, Canada. Thesis. University of Waterloo, Waterloo, Ontario, Canada.

Börger, L., and T. D. Nudds. 2014. Fire, humans, and climate: modeling distribution dynamics of boreal forest waterbirds. Ecological Applications 24:121-141. https://doi.org/10.1890/12-1683.1

Burnham, K. P., and D. R. Anderson. 2002. Model selection and multimodel inference: a practical inormation-theoretic approach. Second edition. Springer-Verlag, New York, New York, USA.

Coulton, D. W., R. G. Clark, L. I. Wassenaar, D. W. Howerter, and M. G. Anderson. 2011. Social and habitat correlates of immigrant recruitment of yearling female Mallards to breeding locations. Journal of Ornithology 152:781-791. https://doi. org/10.1007/s10336-011-0660-y

Crumpton, W. G., and L. G. Goldborough. 1998. Nitrogen transformation and fate in prairie wetlands. Great Plains Research 8:57-72.

Cunningham, M. A., and D. H. Johnson. 2016. What you find depends on where you look: responses to proximate habitat vary with landscape context. Avian Conservation and Ecology 11(2):1. https://doi.org/10.5751/ACE-00865-110201

Doyle, F. I., and J. N. M. Smith. 2001. Raptors and scavengers. Pages 377-404 in C. J. Krebs, S. Boutin, and R. Boonstra, editors. Ecosystem dynamics of the boreal forest: the Kluane project. Oxford University Press, New York, New York, USA.

Dyer, S. J., J. P. O'Neill, S. M. Wasel, and S. Boutin. 2001. Avoidance of industrial development by woodland caribou. Journal of Wildlife Management 65:531-542. https://doi. org/10.2307/3803106

Dyer, S. J., J. P. O'Neill, S. M. Wasel, and S. Boutin. 2002. Quantifying barrier effects of roads and seismic lines on movements of female woodland caribou in northeastern Alberta. Canadian Journal of Zoology 80:839-845. https://doi.org/10.1139/ z02-060

Eagle, T. C., and J. S. Whitman. 1987. Mink. Pages 614-624 in M. Novak, J. A. Baker, M. E. Obbard, and B. Malloch, editors. Wild furbearer management and conservation in North America. Ontario Trappers Association, Ministry of Natural Resources, Peterborough, Ontario, Canada.

Ecological Stratification Working Group. 1995. A national ecological framework for Canada. State of the Environment Directorate, Environmental Conservation Service, Environment Canada, Hull, Quebec, Canada/Centre for Land and Biological Resources Research, Research Branch, Agriculture and AgriFood Canada, Ottawa, Ontario, Canada. [online] URL: http:// sis.agr.gc.ca/cansis/publications/ecostrat/cad_report.pdf

Environment Canada. 2013. Bird conservation strategy for bird conservation region 6: boreal taiga plains. Environment Canada,
Saskatoon, Saskatchewan, Canada. [online] URL: http:// publications.gc.ca/collections/collection_2014/ec/CW66-317-2-2014eng.pdf

Fahrig, L., and T. Rytwinski. 2009. Effects of roads on animal abundance: an empirical review and synthesis. Ecology and Society 14(1):21. https://doi.org/10.5751/ES-02815-140121

Fast, M., B. Collins, and M. Gendron. 2011. Trends in breeding waterfowl in Canada. Canadian Biodiversity: Ecosystem Status and Trends 2010. Technical Thematic Report No. 8. Canadian Councils of Resource Ministers, Ottawa, Ontario, Canada. [online] URL: https://biodivcanada.chm-cbd.net/ecosystemstatus-trends-2010/technical-report-8

Fitzsimmons, M. 2002. Estimated rates of deforestation in two boreal landscapes in central Saskatchewan, Canada. Canadian Journal of Forest Research 32:843-851. https://doi.org/10.1139/ $\mathrm{x} 01-184$

Fleming, W. D. 2001. Effects of pipeline rights-of-way on forest birds in the boreal forest of Alberta. Thesis. University of Alberta, Edmonton, Alberta, Canada.

Foley, J. A., M. H. Costa, C. Delire, N. Ramankutty, and P. Snyder. 2003. Green surprise? How terrestrial ecosystems could affect Earth's climate. Frontiers in Ecology and the Environment 1:38-44. https://doi.org/10.1890/1540-9295(2003)001[0038:GSHTEC]2.0.CO;2

Foote, L., and N. Krogman. 2006. Wetlands in Canada's western boreal forest: agents of change. Forestry Chronicle 82:825-833. https://doi.org/10.5558/tfc82825-6

Forman, R. T. T., and L. E. Alexander. 1998. Roads and their major ecological effects. Annual Review of Ecology and Systematics 29:207-231. https://doi.org/10.1146/annurev.ecolsys.29.1.207

Francis, C. D., C. P. Ortega, and A. Cruz. 2009. Noise pollution changes avian communities and species interactions. Current Biology 19:1415-1419. https://doi.org/10.1016/j.cub.2009.06.052

Francis, C. D., J. Paritsis, C. P. Ortega, and A. Cruz. 2011. Landscape patterns of avian habitat use and nest success are affected by chronic gas well compressor noise. Landscape Ecology 26:1269-1280. https://doi.org/10.1007/s10980-011-9609-z

Gauthier, G., and J. N. M. Smith. 1987. Territorial behavior, nestsite availability, and breeding density in Buffleheads. Journal of Animal Ecology 56:171-184. https://doi.org/10.2307/4807

Global Forest Watch Canada. 2009. Cumulative anthropogenic access, Western Canada. Global Forest Watch, Edmonton, Alberta, Canada [online] URL: https://databasin.org/ datasets/55ec942d370d49fb824bb662d66dfe32

Government of Canada. 2003. Pipeline regulation in Canada: a guide for landowners and the public. National Energy Board, Calgary, Alberta, Canada. [online] URL: http://publications.gc. ca/collections/collection_2016/one-neb/NE23-104-2002-eng.pdf

Granger, R. J., and J. W. Pomeroy. 1997. Sustainability of the western Canadian boreal forest under changing hydrological conditions. II. Summer energy and water use. Sustainability of Water Resources under Increasing Uncertainty. IAHS publication 240:243-249.

Hebert, C. E., and L. I. Wassenaar. 2001. Stable nitrogen isotopes in waterfowl feathers reflect agricultural lands use in western 
Canada. Environmental Science and Technology 35:3482-3487. https://doi.org/10.1021/es001970p

Hethcoat, M. G., and A. D. Chalfoun. 2015. Energy development and avian nest survival in Wyoming, USA: a test of a common disturbance index. Biological Conservation 184:327-334. https:// doi.org/10.1016/j.biocon.2015.02.009

Hobson, K. A., and E. M. Bayne. 2000. Effects of forest fragmentation by agriculture on avian communities in the southern boreal mixedwoods of western Canada. Wilson Ornithological Society 112:373-387. https://doi.org/10.1676/0043-5643 (2000)112[0373:eoffba]2.0.co;2

Hobson, K. A., E. M. Bayne, and S. L. Van Wilgenburg. 2002. Large-scale conversion of forest to agriculture in the Boreal Plains of Saskatchewan. Conservation Biology 16:1530-1541. https://doi. org/10.1046/j.1523-1739.2002.01199.x

Holopainen, S., P. Nummi, and H. Pöysä. 2014. Breeding in the stable boreal landscape: lake habitat variability drives brood production in the teals (Anas crecca). Freshwater Biology 59:2621-2631. https://doi.org/10.1111/fwb.12458

Houlahan, J. E., and C. S. Findlay. 2004. Estimating the 'critical' distance at which adjacent land-use degrades wetland water and sediment quality. Landscape Ecology 19:677-690. https://doi. org/10.1023/B:LAND.0000042912.87067.35

James, A. R. C. 1999. Effects of industrial development on the predator-prey relationships between wolves and caribou in northeast Alberta. Dissertation. University of Alberta, Edmonton, Alberta, Canada.

James, A. R. C., and A. K. Stuart-Smith. 2000. Distribution of caribou and wolves in relation to linear corridors. Journal of Wildlife Management 64:154-159. https://doi.org/10.2307/3802985

Johnson, P. C. D. 2014. Extension of Nakagawa \& Schielzeth's $\mathrm{R}_{\text {GLMM }}^{2}$ to random slopes models. Methods in Ecology and Evolution 5:944-946. https://doi.org/10.1111/2041-210X.12225

Klassen, R. W. 1989. Quaternary geology of the southern Canadian interior plains. Pages 138-174 in R. J. Fulton, editor. Quaternary geology of Canada and Greenland. Geological Survey of Canada, Ottawa, Ontario, Canada.

Kroening, S., and M. Ferrey. 2013. The condition of Minnesota's groundwater, 2007-2011. Minnesota Pollution Control Agency, St. Paul, Minnesota, USA. [online] URL: http://www.pca.state. mn.us/sites/default/files/wq-am1-06.pdf

Kuczynski, E. C., and C. A. Paszkowski. 2012. Constructed borrow-pit wetlands as habitat for aquatic birds in the Peace Parkland, Canada. International Scholarly Research Notices 2012:217357. http://dx.doi.org/10.5402/2012/217357

Lemelin, L. V., L. Imbeau, M. Darveau, and D. Bordage. 2007. Local, short-term effects of forest harvesting on breeding waterfowl and Common Loon in forest-dominated landscapes of Quebec. Avian Conservation and Ecology 2(2):10. https://doi. org/10.5751/ACE-00191-020210

Littell, R. C., G. A. Milken, W. W. Stroup, and R. D. Wolfinger. 1996. SAS system for mixed models. SAS Institute Inc, Cary, North Carolina, USA.
Lindenmayer, D. B., and J. Fischer. 2006. Habitat fragmentation and landscape change: an ecological and conservation synthesis. Island, Washington, D.C., USA.

Longford, N. T. 1993. Regression analysis of multilevel data with measurement error. British Journal of Mathematical and Statistical Psychology 46:301-311. https://doi.org/10.1111/ j.2044-8317.1993.tb01018.x

Loss, S. R. 2016. Avian interactions with energy infrastructure in the context of other anthropogenic threats. Condor 118:424-432. https://doi.org/10.1650/CONDOR-16-12.1

Ludlow, S. M., and S. K. Davis. 2018. Oil and natural gas development influence nest-site selection and nest survival of upland-nesting waterfowl and shorebirds. Wildlife Society Bulletin 42(1):57-66. [online] URL: https://doi.org/10.1002/ wsb. 849

Machtans, C. S. 2006. Songbird response to seismic lines in the western boreal forest: a manipulative experiment. Canadian Journal of Zoology 84:1421-1430. https://doi.org/10.1139/ z06-134

Martell, K. A., A. L. Foote, and S. G. Cumming. 2006. Riparian disturbance due to beaver (Caster canadensis) in Alberta's boreal mixedwood forests: implications for forest management. Ecoscience 13:164-171. https://doi.org/10.2980/i1195-6860-13-2-164.1

Matuschek, H., R. Kliegl, S. Vasishth, H. Baayen, and D. Bates. 2017. Balancing Type I error and power in linear mixed models. Journal of Memory and Language 94:305-315. https://doi. org/10.1016/j.jml.2017.01.001

Moore, W. S. 1995. Northern Flicker (Colaptes auratus). Account 166 in A. Poole and F. Gill, editors. The birds of North America. The Academy of Natural Sciences, Philadelphia, and The American Ornithologists' Union, Washington, D.C., USA.

Morelli F., M. Beim, L. Jerzak, D. Jones, and P. Tryjanowski. 2014. Can roads, railways and related infrastructures have positive effects on birds? A review. Transportation Research Part D: Transport and Environment 30:21-31. https://doi.org/10.1016/j. $\operatorname{trd} .2014 .05 .006$

National Agroclimate Information Service. 2018. Palmer drought index. Science and Technology Branch, Agriculture and AgriFood Canada, Ottawa, Ontario, Canada.

Natural Resources Canada. 2007. Earth observation for sustainable development of forests. Canadian Forest Service, Pacific Forestry Centre, Department of Natural Resources, Ottawa, Ontario, Canada.

Newton, I. 1994. The role of nest sites in limiting the numbers of hole-nesting birds: a review. Biological Conservation 70:265-276. https://doi.org/10.1016/0006-3207(94)90172-4

Niemi, G., J. Hanowski, P. Helle, R. Howe, M. Mönkkönen, L. Vernier, and D. Welsh. 1998. Ecological sustainability of birds in boreal forests. Conservation Ecology 2(2):17. https://doi. org/10.5751/ES-00079-020217

Nudds, T. D., and R. W. Cole. 1991. Changes in populations and breeding success of boreal forest ducks. Journal of Wildlife Management 55:569-573. https://doi.org/10.2307/3809500 
Park, D., M. Sullivan, E. Bayne, and G. Scrimgeour. 2008. Landscape-level stream fragmentation caused by hanging culverts along roads in Alberta's boreal forest. Canadian Journal of Forest Research 38:566-575. https://doi.org/10.1139/X07-179

Partington, M., C. Gillies, B. Gingras, C. Smith, and J. Morissette. 2016. Resource roads and wetlands: a guide for planning, construction and maintenance. FPinnovations (Special Publication SP-530E), Point-Claire, Québec, Canada.

Paton, P. W. C. 1994. The effect of edge on avian nest success: How strong is the evidence? Conservation Biology 8:17-26. https:// doi.org/10.1046/j.1523-1739.1994.08010017.x

Pierre, J. A. 2001. Effects of forest harvesting disturbance on aquatic birds in the boreal forest of Alberta. Thesis. University of Alberta, Edmonton, Alberta, Canada.

Pöysä, H., J. Elmberg, G. Gunnarsson, S. Holopainen, P. Nummi, and K. Sjöberg. 2017. Habitat associations and habitat change: seeking explanation for population decline in breeding Eurasian Wigeon Anas Penelope. Hydrobiologia 785:207-217. https://doi. org/10.1007/s10750-016-2922-4

Pöysä, H., and S. Pöysä. 2002. Nest-site limitation and density dependence of reproductive output in the Common Goldeneye Bucephala clangula: implications for the management of cavity nesting birds. Journal of Applied Ecology 39:502-510. https://doi. org/10.1046/j.1365-2664.2002.00726.x

Prairie Habitat Joint Venture. 2014. Prairie Habitat Joint Venture implementation plan 2013-2020: the western boreal forest. Report of the Prairie Habitat Joint Venture. Environment Canada, Edmonton, Alberta, Canada. [online] URL: https://www.phjv.ca/ wp-content/uploads/2017/10/PHJV-Implementation-Plan-WESTERNBOREAL-2013-2020-Final.pdf

Robinson, S. K., F. R. Thompson III, T. M. Donovan, D. R. Whitehead, and J. Faaborg. 1995. Regional forest fragmentation and the nesting success of migratory birds. Science 267:1987-1990. https://doi.org/10.1126/science.267.5206.1987

Rohner, C. J., F. I. Doyle, and J. N. M. Smith. 2001. Great horned owls. Pages 340-376 in C. J. Krebs, S. Boutin, and R. Boonstra, editors. Ecosystem dynamics of the boreal forest: the Kluane project. Oxford University Press, New York, New York, USA.

Rooney, R. C., S. E. Bayley, and D. W. Schindler. 2012. Oil sands mining and reclamation cause massive loss of peatland and stored carbon. Proceedings of the National Academy of Sciences 109:4933-4937. https://doi.org/10.1073/pnas.1117693108

Roy, C. L. 2018. Nest and brood survival of Ring-necked Ducks in relation to anthropogenic development and wetland attributes. Avian Conservation and Ecology 13(1):20. [online] URL: https:// doi.org/10.5751/ACE-01212-130120

Sargeant, R. J., and D. G. Raveling. 1992. Mortality during the breeding season. Pages 396-422 in B. D. J. Batt, A. D. Afton, M. G. Anderson, C. D. Ankney, D. H. Johnson, J. A. Kadlec, and G. L. Krapu, editors. The ecology and management of breeding waterfowl. University of Minnesota Press, Minneapolis, Minnesota, USA.

Sauer, J. R., D. K. Niven, J. E. Hines, K. L. Pardieck, J. E. Fallon, W. A. Link, and D. J. Ziolkowski, Jr. 2017. The North American breeding bird survey: results and analysis 1966-2015. Version 2.07.2017. USGS Patuxent Wildlife Research Center, Laurel, Maryland, USA. [online] URL: https://www.mbr-pwrc.usgs.gov/ bbs/bbs2015.html

Savard, J. P. 1988. Use of nest boxes by Barrow's Goldeneyes: nesting success and effect on breeding population. Wildlife Society Bulletin 16:125-132.

Schindler, D. W. 1998. Sustaining aquatic ecosystems in boreal regions. Conservation Ecology 2(2):18. https://doi.org/10.5751/ ES-00077-020218

Schmiegelow, F. K. A., and M. Mönkkönen. 2002. Habitat loss and fragmentation in dynamic landscapes: avian perspectives from the boreal forest. Ecological Applications 12:375-389. https:// doi.org/10.1890/1051-0761(2002)012[0375:hlafid]2.0.co;2

Schneider, R. R. 2002. Alternative futures: Alberta's boreal forest at the crossroads. Federation of Alberta Naturalists, Edmonton, Alberta, Canada.

Silver, C. A., J. E. Thompson, A. S. Wong, and S. E. Bayley. 2012. Relationship between wetland macroinvertebrates and waterfowl along an agricultural gradient in the Boreal Transition Zone of western Canada. Northwestern Naturalist 93:40-59. https://doi. org/10.1898/11-03.1

Slattery, S. M., J. L. Morissette, G. G. Mack, and E. W. Butterworth. 2011. Waterfowl conservation planning: science needs and approaches. Pages 23-40 in J. V. Wells, editor. Boreal birds of North America: a hemispheric view of their conservation links and significance. Studies in Avian Biology No. 41. Cooper Ornithological Society, University of California Press, Berkley, California, USA.

Smith, G. W. 1995. A critical review of the aerial and ground surveys of breeding waterfowl in North America. U.S. National Biological Service, Washington, D.C., USA.

Smith, K. G. 2004. Woodland caribou demography and persistence relative to landscape change in west-central Alberta. Thesis. University of Alberta, Edmonton, Alberta, Canada.

Statistics Canada. 2016. Agriculture ecumene boundary file. Statistics Canada Catalogue no. 92-639-X. Agriculture and AgriFood Canada, Ottawa, Ontario, Canada. [online] URL: https:// www150.statcan.gc.ca/n1/pub/92-639-g/92-639-g2016001-eng.htm

Stralberg, D., D. Berteaux, C. Drever, M. Drever, I. NaujokaitisLewis, F. K. A. Schmiegelow, and J. A. Tremblay. 2019. Conservation planning for boreal birds in a changing climate: a framework for action. Avian Conservation and Ecology 14(1):13 [online] URL: https://doi.org/10.5751/ACE-01363-140113

Tigner, D. J. 2012. Measuring wildlife response to seismic lines to inform land use planning decisions in northwest Canada. Thesis. University of Alberta, Edmonton, Alberta, Canada.

Trombulak, S. C., and C. A. Frissell. 2000. Review of ecological effects of roads on terrestrial and aquatic communities. Conservation Biology 14:18-30. https://doi.org/10.1046/ j.1523-1739.2000.99084.X

United States Fish and Wildlife Service, and Canadian Wildlife Service. 1987. Standard operating procedures for aerial waterfowl 
breeding ground population and habitat surveys in North America. U.S. Fish and Wildlife Service, Washington, D.C., USA, and Canadian Wildlife Service, Ottawa, Ontario, Canada.

Väisänen, R. A., O. Järvinen, and P. Rauhala. 1986. How are extensive, human-caused habitat alterations expressed on the scale of local bird populations in boreal forests? Ornis Scandinavica 17:282-292. https://doi.org/10.2307/3676839

Van der Kamp, G., W. J. Stolte, and R. G. Clark. 1999. Drying out of small prairie wetlands after conversion of their catchments from cultivation to permanent brome grass. Hydrological Sciences Journal 44(3):387-397. https://doi.org/10.1080/02626669909492234

Van Rensen, C. K., S. E. Nielsen, B. White, T. Vinge, and V. J. Lieffers. 2015. Natural regeneration of forest vegetation on legacy seismic lines in boreal habitats in Alberta's oil sands region. Biological Conservation 184:127-135. https://doi.org/10.1016/j. biocon.2015.01.020

Vanderhill, B. G. 1982. The passing of the pioneer fringe in western Canada. Geographical Review 72:200-217. https://doi. org/10.2307/214867

Vitt, D. H. 1994. An overview of factors that influence the development of Canadian peatlands. Memoirs of the Entomological Society of Canada 169:7-20. https://doi. org/10.4039/entm126169007-1

Woo, M.-K., and T. C. Winter. 1993. The role of permafrost and seasonal frost in the hydrology of northern wetlands in North America. Journal of Hydrology 141:5-31. https://doi. org/10.1016/0022-1694(93)90043-9 


\section{Appendix 1.}

SAS code for best approximating ground nester's model. All other guilds follow the same approach but can vary by retained predictor variables in their best approximating model.

proc glimmix ic $=$ pq method $=\mathrm{mspl}$;

class segment Ys_cat Landscape_Ag;

model sqrt_v_tip_ground $=$ PERC_WETL PERC_CONI PERC_MIXE PERC_SHRU

PERC_CROP PDI Ys Ys*Ys Ys*SEIS_DEN Ys*WELL Ys*ROAD_DEN

Ys*PIPE_DEN Ys*Ys*SEIS_DEN Ys*Ys*WELL Ys*Ys*ROAD_DEN

Ys*Ys*PIPE_DEN Landscape_Ag*Ys*SEIS_DEN Landscape_Ag*Ys*WELL

Landscape_Ag*Ys*PIPE_DEN Landscape_Ag*Ys*Ys*SEIS_DEN

Landscape_Ag*Ys*Ys*WELL Landscape_Ag*Ys*Ys*PIPE_DEN $/$ dist $=$ normal link $=$ identity ddfm $=$ kenwardroger;

random Ys_cat $/$ type $=\operatorname{ar}(1)$ residual subject=segment;

random int Ys / subject=segment;

run; 


\section{Appendix 2.}

Table A2.1 Expected percent change in pair density for a 5\% increase in each habitat covariate in the top model for each nesting guild and associated habitat parameter estimates $(\beta)$ from bestapproximating anthropogenic disturbance models. Not all habitat types advanced to the final model for each guild.

\begin{tabular}{llrr}
\hline \hline $\begin{array}{l}\text { Nesting } \\
\text { Guild }\end{array}$ & $\begin{array}{l}\text { Habitat } \\
\text { covariates }\end{array}$ & $\beta(\mathrm{SE})$ & $\begin{array}{c}\text { Expected Change in Pair Density } \\
\text { for a 5\% Increase in Habitat } \\
\text { Covariate (\%) }\end{array}$ \\
\hline Cavity & PERC_WETL & $-2.83(0.47)$ & -11.72 \\
& PERC_CONI & $-4.19(0.53)$ & -19.51 \\
& PERC_MIXE & $-3.32(0.97)$ & -13.26 \\
& PERC_SHRU & $-2.65(0.81)$ & -10.86 \\
& PERC_CROP & $-3.94(0.47)$ & -17.17 \\
Ground & PERC_OPWA & $4.93(0.66)$ & 11.19 \\
& PERC_WETL & $-5.57(1.64)$ & -7.56 \\
& PERC_CONI & $-15.37(1.86)$ & -19.43 \\
& PERC_MIXE & $-13.82(3.45)$ & -17.79 \\
& PERC_SHRU & $-9.56(2.84)$ & -12.60 \\
Overwater & PERC_CROP & $-3.78(1.66)$ & -5.18 \\
& PERC_CONI & $-2.22(0.48)$ & -16.03 \\
& PERC_OPWA & $4.93(0.66)$ & 47.89 \\
\hline
\end{tabular}


Appendix 3. Graphical representations of relationships between anthropogenic disturbance variables and duck populations from Tables $2-6$ for each type of landscape.
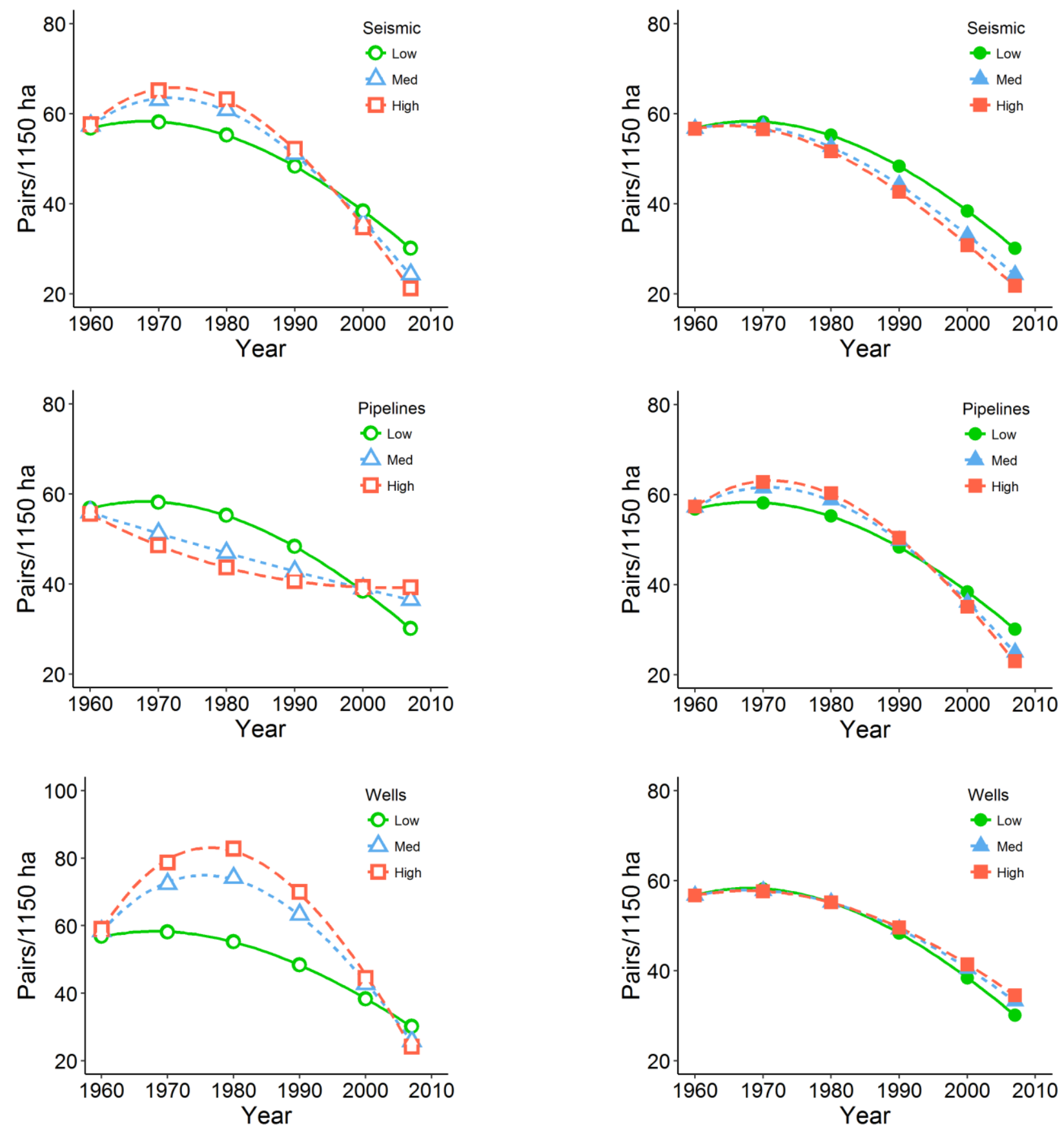

Figure A3.1. Relationships between density of anthropogenic disturbances and trends in ground nesting duck pair density, 1960 - 2007. Open circles- agriculture encroached landscape, close circles - unencroached landscape. Low, medium, high or close, near, far correspond to $25^{\text {th }}, 50^{\text {th }}$, and $75^{\text {th }}$ percentiles. No relationship with landscape was observed for roads. 


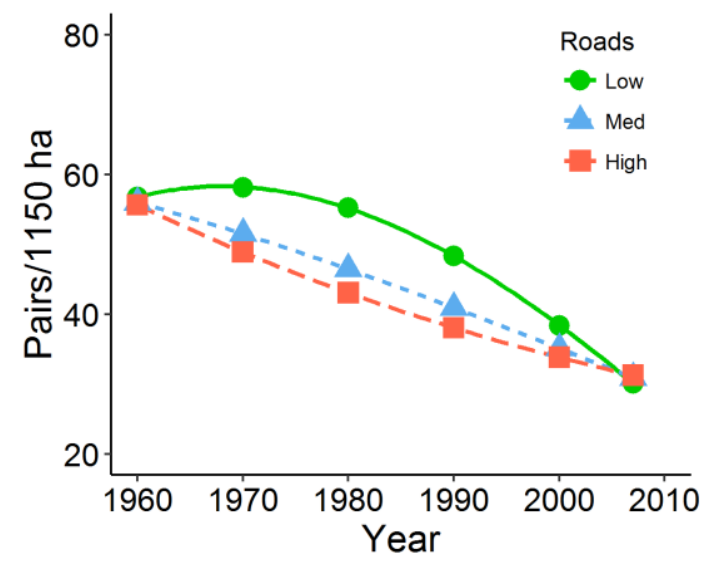

Figure A3.1 cont. 

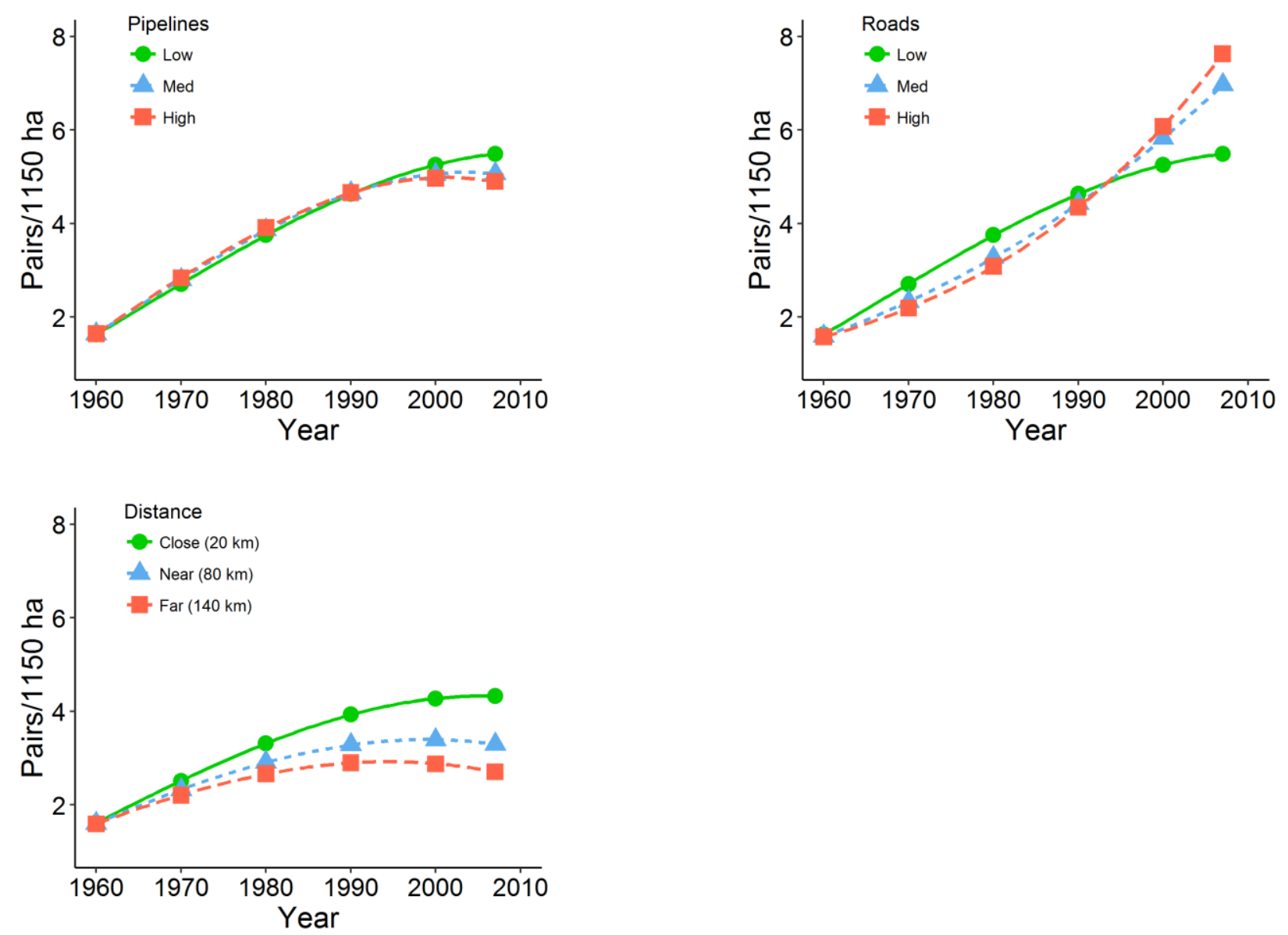

Figure A3.2. Relationships between density of anthropogenic disturbances or distance to agriculture and trends in cavity nesting duck pair density, 1960 - 2007. Low, medium, high or close, near, far correspond to $25^{\text {th }}, 50^{\text {th }}$, and $75^{\text {th }}$ percentiles. No relationship with landscape was observed. 

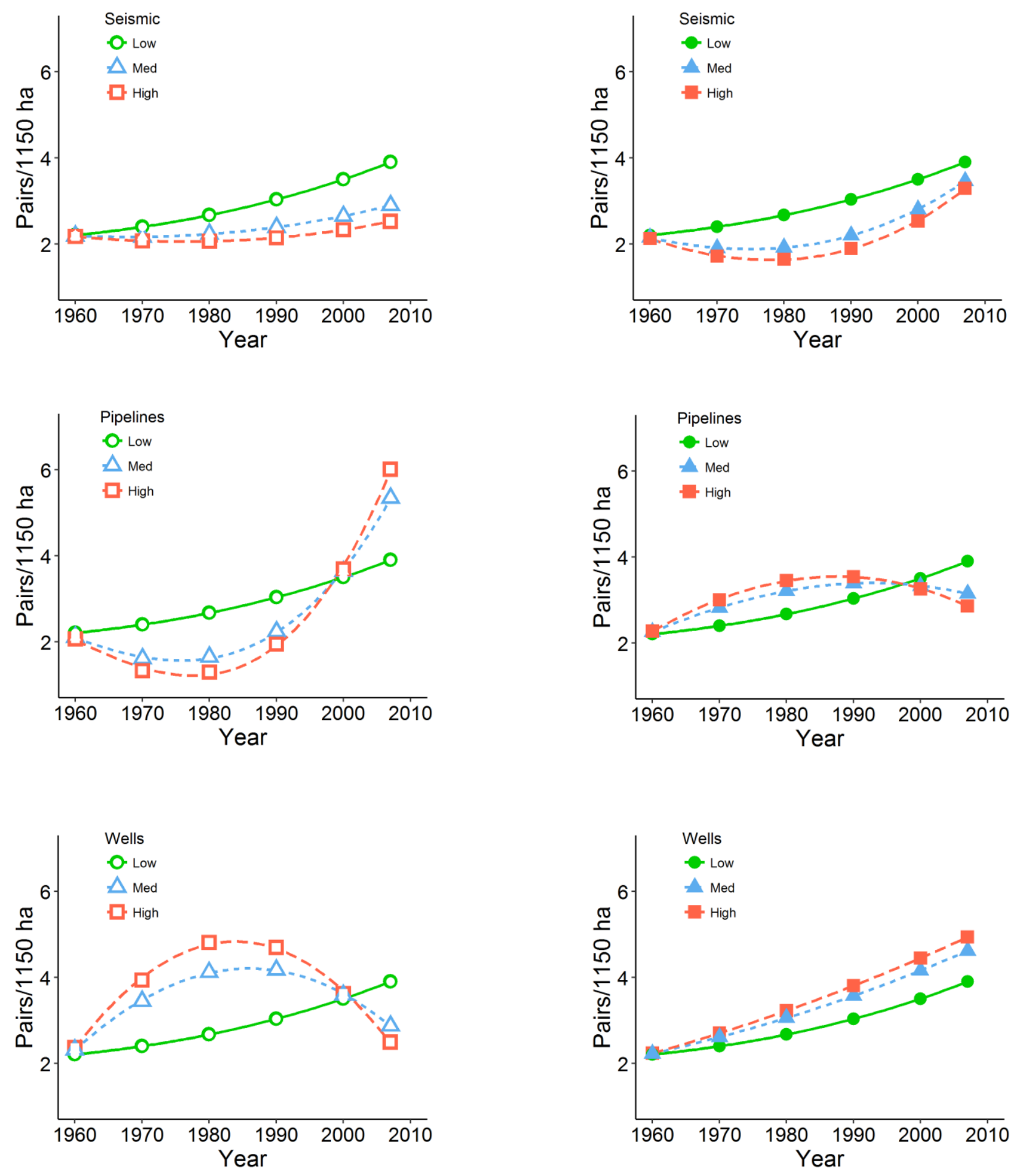

Figure A3.3. Relationships between density of anthropogenic disturbances or distance to agriculture and trends in overwater nesting duck pair density, 1960 - 2007. Open circlesagriculture encroached landscape, close circle - unencroached landscape. Low, medium, high or close, near, far correspond to $25^{\text {th }}, 50^{\text {th }}$, and $75^{\text {th }}$ percentiles. 


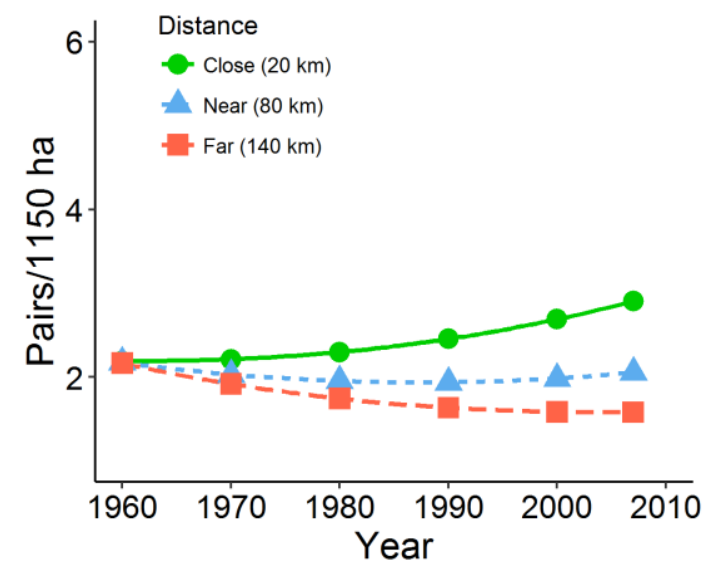

Figure A3.3 cont. 